\title{
Keberpihakan Hukum Islam Terhadap Perlindungan Anak
}

\author{
Siti Nurjanah
}

\begin{abstract}
The Alignment of Islamic Law With Child Protection. Child protection has become an important issue in the modern world. To guarantee the future generations, children must be protected from all forms of of interference, threats, violence and exploitation carried out by adults. Protection is not only charged to parents, but also to the community, nation and state. This article tries to examine the attitude of Islam towards the issue of child protection through a search of syara arguments. Especially in the Qur'an and in the Hadith. This study finds out that Islam has a broader perspective. In guaranteeing the needs of children. The guarantees start when they are still in the wombs (fetus) to adulthood. This can be understood from the provisions of the Shari'ah which prohibits abortion and provide relief for pregnant women not to fast during the month of Ramadan. In addition, Islam also gives rights to children, such as the right to life, the right to have aqiqah (religious redemption), the right to have a good name, the right to receive breastfeeding for two years, and so on.
\end{abstract}

Keyword: child protection, Islamic law, rights to children

\begin{abstract}
Keberpihakan Hukum Islam Terhadap Perlindungan Anak. Perlindungan anak telah menjadi isu penting dalam dunia modern. Untuk menjamin masa depan generasi penerus, anak harus memperoleh perlindungan dari segala macam bentuk gangguan, ancaman, kekerasan dan eksploitasi yang dilakukan oleh orang-orang dewasa. Perlindungan itu tidak hanya dibebankan kepada para orang tua saja, melainkan juga menjadi tanggungjawab masyarakat, bangsa dan negara. Artikel ini mencoba menelaah sikap Islam terhadap isu perlindungan anak melalui penelusuran terhadap dalil-dalil syara. Khususnya Alquran dan al-Hadith. Studi ini menyimpulkan bahwa Islam memiliki perspektif yang lebih komprehensif. dalam menjamin kepentingan anak. Jaminan perlindungan itu dimulai sejak mereka masih berupa janin hingga sesudah mereka tumbuh dewasa. Hal ini dapat dipahami dari ketentuan syari'at yang melarang tindakan abortus dan memberikan keringanan bagi ibu hamil untuk tidak berpuasa pada bulan Ramadan. Selain dari itu, Islam juga memberikan hak hidup, hak untuk diaqiqahkan, hak mendapat nama yang baik, hak mendapatkan penyusuan selama dua tahun, dan sebagainya.
\end{abstract}

Kata Kunci: perlindungan anak, hukum Islam, hak-hak anak 


\section{Pendahuluan}

Hukum menjadi bagian terpenting dalam setiap kehidupan manusia. Baik secara personal maupun kolektif, hukum menjadi "pengikat" dan guide dalam berinteraksi dengan sesama manusia dan lingkungannya. Karena pada dasarnya hukum berasal dari sebuah norma-norma yang terdapat di tengah-tengah masyarakat. Di dalam masyarakat, hukum dapat menghasilkan keteraturan dan keterseimbangan. Namun demikian, untuk menghasilkan hal tersebut, maka mesti terdapat sebuah batasan agar ketidakbebasan tersebut bisa dapat menghasilkan keteraturan.

Perspektif masyarakat Indonesia yang beragam, dengan mayoritas penduduknya beragama Islam, hukum merupakan keniscayaan yang harus diaplikasikan. Sehingga bagi setiap Muslim idealnya-atau mungkin dapat dikatakan wajib-memahami hukum dan permasalahannya, terlebih tentang hukum Islam itu sendiri. ${ }^{1}$ Meski hidup di tengah masyarakat yang heterogen, aktifitas seorang Muslim sehari-hari tidak dapat dilepaskan begitu saja dari permasalahan hukum Islam, baik ketika melakukan ibadah kepada Allah atau ketika bermuâmalâh (melakukan hubungan sosial) di tengah-tengah masyarakat.

Hukum Islam-yang kemudian dalam kontek kekinian lebih dikenal dengan sebutan Islamic law-pada dasarnya berisikan perintah-perintah suci dari Allah Swt bertujuan untuk mengatur aspek kehidupan setiap

${ }^{1}$ Terkait berbagai persoalan hukum Islam kontemporer dapat dilihat dalam karya Mustafa Edwin Nasution, dan Uswatun Hasanah. Wakaf Tunai Inovasi Finansial Islam: Peluang dan Tantangan dalam Mewujudkan Kesejahteraan Umat. Pusat Kajian Timur Tengah dan Islam Universitas Indonesia bekerja sama dengan Bank Indonesia, didukung oleh Departemen Agama RI, 2006. Ayief Fathurrahman. "Meninjau Ulang Landasan Normatif Perbankan Syariah di Indonesia (Telaah atas Teori Kontruksi Fiqh Klasik)." Al-Mawarid 11, no. 1 (2013). Ahwan Fanani. "Ushûl al-Fiqh Versus Hermeneutika Tentang Pengembangan Pemikiran Hukum Islam Kontemporer." Islamica: Jurnal Studi Keislaman 4, no. 2 (2010): h. 194-209. Gatot Suhirman. "Fiqh Mazhab Indonesia (Konsep dan Aplikasi Pemikiran Hasbi as-Siddiqi untuk Konteks Islam Rahmat li-Indonesia)." Al-Mawarid 11, no. 1 (2013). Neni Sri Imaniyati. "Perkembangan Regulasi Perbankan Syariah di Indonesia: Peluang dan Tantangan." Syiar Hukum11, no. 1 (2009): h. 21-38. Badri Khaeruman. "Al-Qaradawi dan Orientasi Pemikiran Hukum Islam untuk Menjawab Tuntutan Perubahan Sosial." Wawasan: Jurnal Ilmiah Agama dan Sosial Budaya 1, no. 2 (2016): h. 227-238. M. Amin Abdullah. "Bangunan Baru Epistemologi Keilmuan Studi Hukum Islam dalam Merespon Globalisasi.” Asy-Syir'ah 46, no. 2 (2012). Fauzi Saleh. "Problematika Talfiq Mazhab dalam Penemuan Hukum Islam." Islamica: Jurnal Studi Keislaman 6, no. 1 (2011): h. 66-73. 
muslim $^{2}$ dan meliputi materi-materi hukum secara murni serta materimateri spiritual keagamaan. ${ }^{3}$ Karenanya, Islamic law merupakan kaidah hukum yang hidup (the living law) ${ }^{4}$ dan berkembang di tengah-tengah masyarakat sejak berabad-abad silam seiring dengan masuknya Islam di Nusantara-dalam catatan CJ. Van Leur diprediksi sejak abad ke-7 M, ${ }^{5}$ jauh sebelum Belanda "mengeksplorasi" kekayaan Nusantara. Dalam hal ini, Joseph Schacht melalui penelitiannya menyebutkan jika Islamic law sebagai ringkasan dari pemikiran Islam, manifestasi way of life Islam yang sangat khas, dan bahkan sebagai inti dari Islam itu sendiri. ${ }^{6}$ Dalam perjalanannya, sejarah Hukum Islam di Nusantara sama halnya dengan sejarah perjalanan hukum adat, juga sebagai hukum yang hidup (the living law) di tengah-tengah masyarakat Indonesia dan menjadi bagian integral yang tak terpisahkan dari masyarakatnya. Namun dalam faktanya, tidak seluruh aspek hukum Islam dan hukum adat menjadi bagian dan berlaku dalam hukum positif di Indonesia. Hal ini dimungkinkan karena intensitas dan suasana politik yang diberlakukan kolonial Belanda ${ }^{7}$ pada saat itu.

2 Joseph Schacht, An Introduction to Islamic Law (Oxford: Oxford University Press, 1964), h. 1. Noel Coulson. A history of Islamic Law (Routledge, 2017). James Norman Dalrymple Anderson. Islamic law in the Modern World (New York University Press, 1959).

${ }^{3}$ S.D. Goitein, "The Birth -Hour of Muslim Law; an Essay in Exegesis," Jurnal The Muslim World (Hartdford: The Hartdford Seminary Foundation) L (1960): h. 23.

${ }^{4}$ Lihat Said Agil Husain Al Munawwar, Islam dan Pluralitas Masyarakat Indonesia (Jakarta: Kaifa, 2004), h. 176.

${ }^{5}$ Lihat CJ. Van Leur dalam Ahmad Mansur Suryanegara, Menemukan Sejarah (Bandung: Mizan, 1995), h. 74-76. Hal ini dapat dibandingkan juga dengan Hasan Muarif Ambary, Menemukan Jejak Arkeologis dan Historis Islam (Jakarta: Logos, 1998), h. 56-58. Dalam pendapat lain juga disebutkan, jika akar sejarah Hukum Islam di kawasan nusantara menurut sebagian ahli sejarah dimulai pada abad pertama hijriyah, atau pada sekitar abad ketujuh dan kedelapan masehi. Lihat Ramly Hutabarat, Kedudukan Hukum Islam dalam Konstitusi-konstitusi Indonesia dan Peranannya dalam Pembinaan Hukum Nasional (Jakarta: Pusat Studi Hukum Tata Negara UI, 2005), h. 61. Sementara itu, Bahtiar Effendy menyebutkan bahwa Islam mulai diperkenalkan di wilayah nusantara pada akhir abad 13 dan awal abad 14 Masehi. Kesimpulan ini sangat mungkin didasarkan pada fakta bahwa kesultanan Islam pertama, Samudra Pasai, berdiri pada kisaran waktu tersebut. Lebih lengkap lihat Bahtiar Effendy, Islam dan Negara: Transformasi Pemikiran dan Praktik Politik Islam di Indonesia (Jakarta: Paramadina, 1998), h. 21.

${ }^{6}$ Joseph Schacht, An Introduction to Islamic Law, h. 1.

${ }^{7}$ Berkaitan dengan hal ini, Bustanul Arifin mengatakan jika dalam tataran sejarah hukum Islam lebih banyak diawali dan diperkenalkan pada masa penjajahan Belanda. Kemungkinan tersebesar, termarginalkannya Hukum Islam pada zaman Belanda akibat panjang dari pola politik jajahan dan penetrasi dari politik hukum kolonial Belanda, serta ditambah dengan rekayasa intelektual kaum 
Perubahan sosial yang ditimbulkan oleh ruang dan waktu secara langsung berpengaruh pada perubahan hukum. Meminjam istilah Harold J. Berman, perubahan hukum menunjuk pada pengertian bahwa hukum selalu mengalami pertumbuhan. ${ }^{8}$ Pertumbuhan hukum memiliki logika internal. Maksudnya, perubahan tidak hanya adaptasi diri dari yang lama terhadap yang baru, tetapi juga bagian dari suatu pola perubahan. Ini tidak terjadi secara acak melainkan dihasilkan dari penafsiran kembali peraturan-peraturan masa lalu dengan keadaan masakini serta kebutuhankebutuhan di masa yang akan datang.

Dalam pertumbuhannya, hukum berinteraksi dengan sektor-sektor kehidupan sosial secara sistemik. Di dalam perjalanannya, di saat terjadinya interaksi dengan kehidupan sosial, terjadi tarik menarik antara realitas dengan idealitas di masyarakat hukum. Pada posisi ini, hukum Islam (Islamic Law) memiliki sifat yang sempurna dan universal. Hukum Islam juga berlaku sepanjang zaman (likulli zamân), yang mencakup seluruh manusia ini tanpa ada batasnya-tidak dibatasi pada negara tertentu, benua, daratan, atau lautan-dan tidak hanya mengatur aspek legal kemasyarakatan tetapi juga mengatur kepentingan-kepentingan ukhrawî.

Hal ini senada dengan tujuan syariat Islam, yaitu mewujudkan kemaslahatan individu dan masyarakat dalam dua bidang, dunia dan akhirat. Tidak ada satu bidang keyakinan atau aktivitas insani atau sebuah kejadian alam kecuali ada pembahasannya dalam syariat Islam yang dikaji dengan segala cara panjang yang luas dan mendalam. ${ }^{10}$ Namun demikian, dalam konteks hukum Islam, pergumulan hukum Islam dengan realitas zaman menuntut timbulnya pertanyaan ulang terhadap produk-produk pemikiran ulama terdahulu, terutama jika direlevansikan dengan spektrum

cerdik cendikia Belanda, yang secara masif dan sistemik memarginalkan Hukum Islam. Lebih lengkap lihat Bustanul Arifin, Dimensi Hukum Islam dalam Hukum Nasional (Jakarta: Gema Insani Press, 1999), h. 33.

${ }^{8}$ Harold J Berman, Law and Revolution: The Formation of the Western Legal Tradition (Cambridge: Massachusetts and London, England, Harvard University Press, 1983), h. 9.

9 Muhammad Muslehuddin, Filsafat Hukum Islam dan Pemikiran Orientalis Studi Perbandingan Sistem Hukum Islam (Yogyakarta: PT. Tiara Wacana Yogya, 1991), h. 47.

${ }^{10}$ Rasyad Hasan Halil, Tarikh Tasyri' Sejarah Legislasi Hukum Islam (Jakarta: Amzah, 2009), h. 22. 
masalah dewasa ini yang semakin luas dan kompleks. ${ }^{11}$

Jika dikaji dari perspektif masyarakat Indonesia yang multikultural dan kaya akan budaya, hukum Islam (Islamic law) sebagai salah satu sistem hukum yang juga berlaku di Indonesia, mestinya mampu memberikan peran dan keberfungsiaannya. Hukum Islam memiliki kontribusi yang sangat urgen dalam rangka menciptakan dan melaksanakan pembangunan manusia seutuhnya, yakni baik pembangunan dunia maupun pembangunan akhirat-di bidang materil, maupun di bidang mental-spiritual. ${ }^{12}$ Di sinilah terlihat jika ruang lingkup hukum Islam tidak ter-margin atau terbatas pada pemeluk dan penganutnya saja, akan tetapi mengakomodir setiap hak asasi manusia. Artinya, hukum Islam tidak hanya mengatur hubungan manusia dengan Tuhan, tetapi juga hubungan antara manusia dengan dirinya sendiri, manusia dengan manusia lain dalam masyarakat, manusia dengan benda, dan antara manusia dengan lingkungan hidupnya. Hal tersebut juga telah ditegaskan di dalam Alquran sebagai dasar hukum Islam yang utama, banyak memuat ayat-ayat yang berkaitan dengan masalah pemenuhan dan perlindungan terhadap hak asasi manusia serta larangan bagi seorang muslim untuk melakukan pelanggaran hak asasi manusia. Hal inilah yang membedakan secara kontras tentang pandangan hak asasi manusia menurut pandangan masyarakat Barat dengan hak asasi manusia perspektif Islam. ${ }^{13}$

${ }^{11}$ Mukhammad Ilyasin, "Filsafat Hukum Islam: Implikasi Logis terhadap Konstruksi Pendidikan Islam," Asy-Syir'ah: Jurnal Ilmu Syariah dan Hukum 46, no. 2 (Desember 2012): h. 552.

${ }_{12}$ Terkait kontribusi hukum Islam terhadap perkembangan peradaban bisa dilihat pada karya M. Hasan Ubaidillah. "Kontribusi Hukum Islam dalam Mewujudkan Good Governance di Indonesia." Al-Qanun: Jurnal Pemikiran dan Pembaharuan Hukum Islam 11, no. 1 Juni (2008): h. 112-141. Ali Imron. "Kontribusi Hukum Islam Terhadap Pembangunan Hukum Nasional (Studi Tentang Konsepsi Taklif dan Masuliyyat dalam Legislasi Hukum).” PhD diss., program Pascasarjana Universitas Diponegoro, 2008. Andi Rasdiyanah. "Kontribusi Hukum Islam dalam Mewujudkan Hukum Pidana Nasional." In Makalah Disampaikan pada Upacara Pembukaan Seminar Nasional tentang Kontribusi Hukum Islam Terhadap Terwujudnya Hukum Pidana Nasional yang Berjiwa Kebangsaan, UII-Yogyakarta, vol. 2. 1995. Abdul Hadi, dan Shofyan Hasan. "Pengaruh Hukum Islam dalam Pengembangan Hukum di Indonesia." Nurani: Jurnal Kajian Syariah dan Masyarakat 15, no. 2 (2015): h. 89-100. Ali Imron. "Kontribusi Hukum Islam Terhadap Pembangunan Hukum Nasional." Jurnal MMH (2008). M Sularno. "Syari'at Islam dan Upaya Pembentukan Hukum Positif di Indonesia." Al-Mawarid 16 (2006). Sirojul Munir. "Pengaruh Hukum Islam Terhadap Politik Hukum Indonesia." Istinbath: Jurnal Hukum Islam IAIN Mataram 13, no. 2 (2014): h. 127-180.

${ }^{13}$ Menurut Muhamad Ahmad Mufti dan Sami Salih al-Wakil, Pemikiran Barat memandang 


\section{Eksistensi Anak dalam Pandangan Islam dan Negara}

Meskipun berada dalam posisi keterbatasan, yakni hukum Islam sebagai hukum positif (hukum nasional)-tidak lantas menghilangkan nilai-nilai keagungannya sebagai agama rahmatan lil'alamîn dengan menjunjung tinggi hak asasi manusia dan memperhatikan keselamatan umat manusia di muka bumi ini. Salah satu hal dari banyak tema yang mendapat perhatian secara serius dalam hukum Islam adalah tentang anak. Sejak awal-atau bahkan jauh sebelum adanya indikasi tentang munculnya Undang-Undang Perlindungan terhadap Anak-agama Islam, secara serius telah terlebih dulu melestarikan dan menjunjung tinggi nilai-nilai kemanusiaan dengan terbitnya ayat-ayat yang membahas perlindungan dan pemberian hak-hak terhadap anak.

Dalam hal ini Alquran telah banyak membahas dan mengisyaratkan kepada manusia bahwa perlindungan terhadap anak pada dasarnya adalah tugas dan kewajiban dari orang tua yang harus dilakukan sejak kecil. ${ }^{14}$

bahwa hak-hak asasi manusia merupakan hak-hak alamiyah (al-huquq athabiizyah/natural right) yang mengalir dari ide bahwa kedaulatan mutlak adalah milik manusia, tidak ada pihak lain yang lebih berdaulat dari manusia (antrophocentris). Sedangkan dalam Islam hak-hak dasar manusia sebagai anugerah yang diberikan Allah Swt (theosentris). Lebih lengkap lihat Muhamad Ahmad Mufti dan Sami Salih al-Wakil, HAM Menurut Barat dan HAM Menurut Islam, trans. oleh Yahya Abd Rahman (Bogor: Pustaka Thariqul Izzah, 2009), h. 22.

${ }^{14}$ Penyandaran tugas dan kewajiban ini mengacu pada istilah-istilah yang terdapat di dalam Alquran, yaitu istilah ibn pada anak. Kata ini masih seakar dengan kata bana yang berarti membangun atau berbuat baik. Adapun secara semantis anak ibarat sebuah bangunan yang harus diberi pondasi yang kokoh, orang tua harus memberikan pondasi keimanan, akhlak dan ilmu sejak kecil, agar ia tumbuh dan berkembang menjadi anak yang memiliki prinsip serta kepribadian yang teguh. Lihat Abdul Mustakim, "Kedudukan dan Hak-hak Anak dalam Perspektif al-Qur'an," Jurnal Musawa 4, no. 2 (Juli 2006): h. 149-50. Selanjutnya, kata ibn sering juga digunakan dalam bentuk tashghir sehingga berubah menjadi bunayya yang menunjukkan anak secara fisik masih kecil dan menunjukkan adanya hubungan kedekatan (al-iqtirâb). Panggilan yâ bunayya (wahai anakku) menyiratkan anak yang dipanggil masih kecil dan hubungan kedekatan dan kasih sayang antara orang tua dengan anaknya. Begitulah mestinya hubungan orang tua dengan anak, hubungan yang dibangun dalam fondasi yang mengedepankan kedekatan, kasih sayang dan kelembutan. Sikap orang tua yang mencerminkan kebencian dan kekerasan terhadap anak jelas tidak dibenarkan dalam Alquran. Lebih lanjut lihat Hadlarat Hifni Bik Nasif dkk, Qawa'id al-Lughah al-Arabiyyah (Surabaya: Syirkah Maktabah wa Mathba'ah, t.t.), h. 79. Bandingkan juga bahwa dalam kamus bahasa Arab,anak disebut juga dengan walad, satu kata yang mengandung penghormatan, sebagai makhluk Allah yang sedang menempuh perkembangan ke arah abdi Allah yang saleh. Pendapat Ibnu Abbas salah seorang ahli tafsir dikalangan sahabat Nabi Muhammad Saw dalam penafsiran kata walad pada ayat 176 surat al-Nisa' mempunyai pengertian mencakup baik anak laki-laki maupun anak perempuan. Pandangan ini sangat berbeda dengan ijmâ para fuqahâ dan ulama yang dianut selama ini, bahwa yang dimaksud dengan walad dalam ayat tersebut hanya anak 
Sumber hukum Islam, Alquran sebagai telah mendeskripsikan dan mengeksplorasi hak serta kepentingan terhadap anak sebagai generasi penerus. Berkaitan dengan perlindungan hukum terhadap anak, secara umum Alquran telah menggambarkan hak-hak dasar kemanusiaan yang tidak seorang pun, kelompok atau bangsa manapun yang bisa membatasi bahkan menekan hak-hak tersebut. ${ }^{15}$

Dalam ajaran Islam, anak memiliki kedudukan yang "spesial”. Anak memiliki makna dan cakupan yang luas, yakni anak merupakan titipan Allah kepada orang tua, masyarakat, bangsa dan negara pewaris dari ajaran Islam (wahyu Allah Swt) yang kelak akan memakmurkan dunia sebagai rạmatan lil âlamîn. ${ }^{16}$ Karenanya, hak anak harus diakui dan diyakini, serta diamankan sebagai implementasi amalan yang diterima oleh anak dari orang tua, masyarakat, bangsa dan Negara.

Pada hakikatnya Perlindungan anak adalah segala usaha yang dilakukan untuk menciptakan kondisi agar setiap anak dapat melaksanakan hak dan kewajibannya demi perkembangan dan pertumbuhan anak secara wajar baik fisik, mental dan sosial. Perlindungan anak merupakan perwujudan adanya keadilan dalam suatu masyarakat, dengan demikian perlu dukungan anak diusahakan dalam berbagai bidang kehidupan bernegara dan bermasyarakat. Arif Gosita mengemukakan bahwa kepastian

laki-laki saja, tidak termasuk anak perempuan. Namun demikian, pengertian walad dalam nash bisa berarti laki-laki dan juga bisa berarti perempuan. Lebih jauh lihat Abdul Wahab Khallaf, Ilmu Ushul al-Figh (Cairo: Maktabah al-Dakwah al-Islamiyah Shabab al-Azhar, 1990), h. 95.

${ }^{15}$ Adapun hak-hak dasar manusia sebagaimana digariskan dalam Alquran adalah sebagai berikut: (a) Hak hidup; (b) Hak milik; (c) Hak perlindungan kehormatan; (c) Keamanan dan kesucian kehidupan pribadi; (d) Hak keamanan kemerdekaan pribadi; (e) Hak perlindungan hukum dari kesewenang-wenangan; (f) Hak menyatakan pendapat dan kebebasan berekspresi; (g) Hak kebebasan berserikat; (h) Hak kebebasan bertempat tinggal; (i) Hak persamaan kedudukan di masyarakat; (j) Hak mendapatkan keadilan; (k) Hak menyatakan penghidupan yang layak; (l) Hak memperoleh pengetahuan. Lihat Juraidi, Jerat Perbudakan Masa Kini (Jakarta: Bina Purna Pariwara, 2003), h. 75.

${ }^{16}$ Pengertian anak dalam Islam disosialisasikan sebagai makhluk ciptaan Allah Sws yang arif dan berkedudukan mulia yang keberadaanya melalui proses penciptaan yang berdimensi pada kewenangan kehendak Allah Swt. Sementara itu secara rasional, seorang anak terbentuk dari unsur gaib yang transcendental dari proses ratifiksi sain (ilmu pengetahuan) dengan unsurunsur ilmiah yang diambil dari nilai-nilai material alam semesta dan nilai-nilai spiritual yang diambil dari proses keyakinan (tauhid Islam). Lebih lanjut lihat Iman Jauhari, Advokasi HakHak Anak Ditinjau dari Hukum Islam dan Peraturan Perundang-undangan (Medan: Pusataka Bangsa, 2008), h. 50. 
hukum perlu diusahakan demi kelangsungan kegiatan perlindungan anak dan mencegah penyelewengan yang membawa akibat negatif yang tidak diinginkan dalam pelaksanaan perlindungan anak. ${ }^{17}$

Posisi hukum Islam sebagai salah satu norma yang dianut dalam masyarakat Indoneisa perlu dijadikan landasan dalam mengkaji persoalan perlindungan anak. Elastisitas hukum Islam dengan prinsip shâlih li kulli zamân wa makân dan prinsip al-hukmu yadûru mảal illati wujûdan wa 'adaman menghendaki dilakukannya analogi dan interpretasi baru sesuai dengan konteks fenomena kejahatan yang terjadi pada anak saat ini. Nilai transedental yang melekat pada norma hukum Islam, merupakan kelebihan tersendiri yang menyebabkan penganutnya lebih yakin bahwa jika ajaran agama dipahami dengan baik, maka akan disadari pula betapa agama tidak menghendaki terjadinya eksploitasi sesama manusia. Nilai-

17 Armando Brilian, "Perlindungan Hukum Terhadap Anak yang Menjadi Korban Tindak Pidana Perkosaan", Lex Crimen 2, No. 7, (November 2013): h. 58. MG Endang Sumiarni. Perlindungan Hukum Terhadap Anak dalam Hukum Pidana. (Yogyakarta: Universitas Atma Jaya Yogyakarta, 2003). Endang Sumiarni, dan Chandera Halim. "Perlindungan Hukum Terhadap Anak dalam Hukum Keluarga.” (Yogyarakarta: Universitas Atmajaya, 2000). Gultom Maidin. "Perlindungan Hukum Terhadap Anak dan Perempuan." (Bandung: Refika Adidatama, 2012). Endang Sumiarni, dan Chandra Halim. "Perlindungan Hukum terhadap Anak Dibidang Kesejahteraan." (Yogyakarta: Universitas Atma Jaya 2000). Netty Endrawati. "Perlindungan Hukum Terhadap Pekerja Anak di Sektor Informal (Studi Kasus di Kota Kediri)." Jurnal Dinamika Hukum 12, no. 2 (2012): h. 270-283. Paulus Hadisuprapto. "Masalah Perlindungan Hukum Bagi Anak." In Seminar Nasional Peradilan Anak, Bandung, Fakultas Hukum Universitas Padjajaran. 1996. Haryanto Dwiatmodjo. "Pelaksanaan Perlindungan Hukum Terhadap Anak yang Menjadi Korban Tindak Pidana di Wilayah Hukum Pengadilan Negeri Banyumas." Jurnal Dinamika Hukum 11, no. 2 (2011): h. 201-213. Evi Deliana HZ. "Perlindungan Hukum Terhadap Anak dari Konten Berbahaya dalam Media Cetak dan Elektronik." Jurnal Ilmu Hukum Riau 3, no. 2 (2012). Andriyani Mustika Nurwijayanti. "Eksploitasi Anak: Perlindungan Hukum Anak Jalanan dalam Perspektif Hukum Pidana di Daerah Yogyakarta." PhD diss., Universitas Muhammadiyah Surakarta, 2012. Marsaulina Nainggolan, Elvi Zahara, dan Saparuddin Saparuddin. "Peranan Hakim dalam Memberikan Perlindungan Hukum Terhadap Anak Korban Penyalahgunaan Narkotika (Studi Pengadilan Negeri Lubuk Pakam)." Jurnal Mercatoria 3, no. 2 (2010): h. 116-132. Sontan Merauke Sinaga, dan Elvi Zahara Lubis. "Perlindungan Hukum Terhadap Anak yang Melakukan Kejahatan dalam Persidangan Anak.” Jurnal Mercatoria 3, no. 1 (2010): h. 52-57. Ira Dwiati. "Perlindungan Hukum Terhadap Korban Tindak Pidana Perkosaan dalam Peradilan Pidana.” PhD diss., Program Pasca Sarjana Universitas Diponegoro, 2007. Elly Sudarti. "Perlindungan Hukum Terhadap Anak dalam Proses Ajudikasi." Jurnal Ilmu Hukum Jambi 2, no. 2 (2014). Noer Indirati. "Pengembangan Model Perlindungan Hukum Terhadap Anak sebagai Korban Perdagangan di Indonesia." Jurnal Dinamika Hukum 14, no. 3 (2014): h. 406418. Ariyunus Zai, dan Taufik Siregar. "Perlindungan Hukum Terhadap Anak yang Berhadapan dengan Hukum dalam Sistem Peradilan Anak (Studi pada Wilayah Hukum Polres Nias).” Jurnal Mercatoria 4, no. 2 (2011): h. 99-116. 
nilai penegakan keadilan, pencegahan kezaliman dan perlunya kerjasama dalam mengatasi masalah-masalah sosial merupakan misi kemanusiaan yang dibawa agama. Namun demikian, nilai-nilai tersebut perlu senantiasa diaktualkan dan diinterpretasikan kembali sesuai dengan perkembangan terbaru modus kejahatan. ${ }^{18}$

Selanjutnya, dalam kontek kenegaraan perihal tentang perlindungan anak, berkembang dan berubah menjadi sebuah kewajiban dan tanggung jawab bersama, yaitu negara, pemerintah dan masyarakat. ${ }^{19}$ Masingmasing elemen tersebut mendapat porsi, tugas dan tanggung jawab dalam memberikan perlindungan kepada anak. Maksud dan tujuannya adalah agar anak-anak dapat hidup, tumbuh, berkembang dan berpartisipasi secara optimal sesuai dengan harkat dan martabat kemanusiaan, serta mendapatkan perlindungan dari kekerasan dan diskriminasi. Oleh sebab itu, agar setiap anak kelak memikul tanggung jawab sebagai tunas, potensi dan generasi muda, penerus cita-cita perjuangan bangsa, maka anakanak perlu mendapatkan kesempatan seluas-luasnya untuk hidup dan berkembang secara optimal, baik secara fisik, mental, sosial serta berakhlak mulia. Sehingganya untuk mewujudkan hal tersebut, perlu adanya tindakan preventif sebagai upaya perlindungan dan pemberian jaminan terhadap pemenuhan hak-haknya. Pada konteks ini negara bahkan dunia internasional telah merumuskan aturan tentang perlindungan anak. ${ }^{20}$

${ }^{18}$ Djaenab, "Perlindungan Anak Perspektif Fiqh dan Perundang-undangan," Jurnal AlRisalah 10, no. 1 (Mei 2010): h. 3.

${ }_{19}$ Tim Redaksi, Undang-undang Perlindungan Anak: Undang-undang RI Nomor 23 Tahun 2002 (Bandung: Fokusmedia, 2007), h. 9.

${ }^{20}$ Dalam upaya melindungi anak, dunia internasional bersepakat untuk membuat sebuah aturan yang mengatur tentang perlindungan anak. Maka pada tanggal 28 November 1989 Majelis Umum PBB telah mensahkan Konvensi Hak Anak (KHA). Setahun setelah itu Konvensi Hak Anak ini disahkan maka pada tanggal 25 Agustus 1990 Pemerintah Indonesia meratifikasi Konvensi tersebut melalui Keputusan Presiden No. 36 tahun 1990 dan mulai berlaku sejak 5 Oktober 1990. Dengan ikutnya Indonesia dalam mensahkan konvensi tersebut maka Indonesia terikat dengan Konvensi Hak Anak dengan segala konsekuensinya. Artinya setiap yang menyangkut tentang kehidupan anak harus mengacu kepada Konvensi Hak Anak dan tak ada pilihan lain kecuali melaksanakan dan menghormati Konvensi Hak Anak. Dan apabila Indonesia tidak melaksanakan dan menghormatinya maka akan memiliki pengaruh negatif dalam hubungan internasional. Dalam mewujudkan pelaksanaan dari Konvensi Hak Anak tersebut maka Pemerintah Indonesia telah membuat aturan dalam upaya melindungi anak. Aturan hukum tersebut tertuang dalam Undang-Undang No. 23 Tahun 2002 tentang Perlindungan Anak yang disahkan pada tanggal 22 Oktober 2002. Jadi jelaslah bahwa perlindungan anak mutlak harus dilakukan karena mulai 
Selain beriktiar dengan menggunakan hukum Islam, di Indonesia aspek legalitas perlindungan terhadap anak diwujudkan dengan dihadirkan dan diakuinya Undang-Undang No. 23 Tahun 2002 Tentang Perlindungan Anak. Sebagaimana termaktub dalam pasal 2 UU No. 23 Tahun 2002 bahwa perlindungan anak diselenggarakan berdasarkan asas Pancasila dan berlandaskan pada UUD RI Tahun 1945 serta dengan mengacu pada prinsip-prinsip dasar konvensi hak-hak anak. ${ }^{21}$ Lebih lanjut di dalam pasal 59 Undang-Undang Perlindungan Anak, disebutkan bahwa perlindungan khusus wajib diberikan kepada anak yang berhadapan dengan hukum. Dalam pasal 64 ayat 1 dan 2 menyebutkan bahwa anak-anak yang berhadapan dengan hukum adalah anak-anak yang berkonflik dengan hukum dan anak korban kejahatan Selain itu, perlindungan terhadap anak juga sudah dijamin secara konstitusional dalam Undang-Undang Dasar 1945 sebagai landasan konstitusional. ${ }^{22}$

Aspek tersebut semakin menguatkan basis perlindungan terhadap anak. Secara kontinu, upaya perlindungan terhadap anak merupakan sebuah keniscayaan dari barbagai elemen dan unsur yang ada di negara ini. Sehingga kesejahteraan anak akan tetap terpelihara, mengingat anak merupakan salah satu aset berharga bagi kemajuan suatu bangsa dikemudian hari.

dari tingkat internasional dan nasional sudah memiliki instrumen hukum. Lebih lengkap Imam Purwadi dalam Muhammad Zaki, "Perlindungan Anak dalam Perspektif Islam," Jurnal ASAS 6, no. 2 (Juli 2014): h. 3.

${ }^{21}$ Prinsip-prinsip dasar Konvensi Hak-Hak Anak meliputi: (a) non diskriminasi; (b) kepentingan yang terbaik bagi anak; (c) hak untuk hidup, kelangsungan hidup, dan perkembangan; dan (d) penghargaan terhadap pendapat anak. Lihat Tim Redaksi, Undang-undang Perlindungan Anak: Undang-undang RI Nomor 23 Tahun 2002, h. 5-6. Peraturan perundang-undangan lain yang telah dibuat oleh pemerintah Indonesia untuk memberikan perlindungan hak terhadap anak antara lain: Undang-Undang No. 4 Tahun 1979 tentang Kesejahteraan anak, Undang-Undang Nomor 39 Tahun 1999 tentang Hak Asasi Manusia, dan Undang-Undang Nomor 3 Tahun 1997 tentang Pengadilan Anak. Secara substansi Undang-Undang tersebut mengatur hak-hak anak yang berupa, hak hidup, hak atas nama, hak pendidikan, hak kesehatan dasar, hak untuk beribadah menurut agamanya, hak berekspresi, berpikir, bermain, berkreasi, beristirahat, bergaul dan hak jaminan sosial.

${ }^{22}$ Prints Rayenda Giovani. "Perlindungan Hukum Terhadap Anak Korban Kejahatan Perkosaan dalam Pemberitaan Media Masa”, Jurnal Mahupiki Fakultas Hukum Universitas Sumatera Utara 1, No. 1, (2013): h. 7. 
Dari segi kualitas, mestinya perlindungan terhadap anak memiliki derajat dan tingkatan yang sama, sebagaimana halnya perlindungan terhadap orang dewasa. Sehingga, setiap orang memiliki kedudukan yang sama di hadapan hukum (equality before the law). Karenanya, negara harus berperan aktif secara bersama-sama dengan segenap masyarakat untuk mewujudkan dan memberikam perlindungan yang memadai kepada anakanak dari berbagai bentuk kekerasan dan manipulasi yang dilakukan oleh orang-orang yang tidak bertanggungjawab yang memanfaatkan anak-anak sebagai wahana kejahatannya, ${ }^{23}$ agar anak sebagai generasi penerus bangsa dapat berdiri dengan kokoh dalam memasuki kehidupan yang semakin keras di masa yang akan datang.

Secara hukum, anak juga memiliki "keistimewaan tersendiri". Anak merupakan objek sekaligus subjek utama dalam suatu proses legitimasi, generalisasi dan sistematika aturan yang mengatur tentang anak. Perlindungan secara hukum inilah yang akan memberikan dasar

${ }^{23}$ Terkait kejahatan kepada anak, telah banyak akademisi membahasnya di antaranya Nur Hidayati. "Perlindungan Anak terhadap Kejahatan Kekerasan Seksual (Pedofilia)." Ragam Jurnal Pengembangan Humaniora 14, no. 1 (2014): h. 68-73. I. Noviana. Kekerasan Seksual Terhadap Anak: Dampak dan Penanganannya. Sosio Informa. (2015). Ratih Probosiwi, dan Daud Bahransyaf. "Pedofilia dan Kekerasan Seksual: Masalah dan Perlindungan Terhadap Anak." Sosio Informa (2015). Dheny Wahyudi. "Perlindungan Terhadap Anak yang Berhadapan dengan Hukum Melalui Pendekatan Restorative Justice." Jurnal Ilmu Hukum Jambi 6, no. 1 (2015). John D Passalbessy. "Dampak Tindak Kekerasan Terhadap Perempuan dan Anak serta Solusinya." Jurnal Sasi 16, no. 3 (2010). Lianny Solihin. "Tindakan Kekerasan pada Anak dalam Keluarga." Jurnal Pendidikan Penabur 3, no. 3 (2004): h. 133. Annisa Jihan Andari. "Analisis Viktimisasi Struktural Terhadap Tiga Korban Perdagangan Perempuan dan Anak Perempuan.” Jurnal Kriminologi Indonesia 7, no. 3 (2012). Fitri Wahyuni. "Sanksi Pidana Pemerkosaan Terhadap Anak Menurut Hukum Pidana Positif dan Hukum Pidana Islam." Jurnal Media Hukum 23, no. 1 (2016): 15. Ayu Amalia Kusuma. "Efektivitas Undang-Undang Perlindungan Anak dalam Hubungan dengan Perlindungan Hukum Terhadap Anak Korban Perdagangan Orang di Indonesia." Lex Et Societatis 3, no. 1 (2015). Irwan Safaruddin Harahap. "Perlindungan Hukum Terhadap Anak Korban Kejahatan Seksual dalam Perspektif Hukum Progresif." Jurnal Media Hukum 23, no. 1 (2016): h. 11. Muhammad. "Aspek Perlindungan Anak dalam Tindak Kekerasan (Bullying) terhadap Siswa Korban Kekerasan di Sekolah (Studi Kasus di Smk Kabupaten Banyumas).” Jurnal Dinamika Hukum 9, no. 3 (2009): h. 268-274. Rusni. "Fenomena Kekerasan Seksual Terhadap Anak." Shautut Tarbiyah 35, no. 2 (2017): h. 51-68. Oksidelfa Yanto. "Prostitusi Online Sebagai Kejahatan Kemanusiaan Terhadap Anak: Telaah Hukum Islam dan Hukum Positif." Ahkam: Jurnal Ilmu Syariah 16, no. 2 (2016): h. 187-196. A. Wira Pratiwi. "Tinjauan Yuridis Tindak Pidana Persetubuhan Terhadap Anak Secara Berlanjut.” Jurnal Fakultas Hukum (2012). A. Nadia, Penganiayaan Terhadap Anak dalam Keluarga. Dalam Makalah Seminar Kekerasan Anak: Efek Psikis, Fisik, dan Tinjauan Agama (September 2004): h. 13-19. 
dan kekuatan perlidungan hukum terhadap eksistensi dan hak-hak anak. ${ }^{24}$ Perlindungan hukum itu sendiri sangat diperlukan dan dibutuhkan oleh masyarakat. Sebab, perlindungan hukum merupakan gambaran dari bekerjanya fungsi hukum untuk mewujudkan tujuan-tujuan hukum, yakni keadilan, kemanfaatan dan kepastian hukum. Perlindungan hukum mestinya diaplikasikan tanpa pandang bulu, siapapun berhak untuk mendapatkannya.

Di Negara Indonesia perlindungan anak merupakan fenomena tersendiri dan cukup menyita perhatian dari berbagai kalangan, yaitu munculnya beragam kasus dan kejadian yang melibatkan anak-anak. Sehingga posisi dan kondisi anak-anak sudah berada pada titik yang memilukan hati dan mengkhawatirkan. Sebagaimana kasus-kasus mengemuka yang melibatkan anak-anak antara lain; orang tua kandung yang tega meradupaksa anaknya sendiri untuk memuaskan hawa nafsunya. Selain itu, banyak juga anak-anak yang dieksploitasi di jalanan, di kereta api, di bis, di pasar dan pabrik. Anak-anak disuruh mengamen, mengemis dan bekerja sepanjang hari untuk memenuhi kebutuhan hidup seperti yang dilakukan oleh orang dewasa. Rekam jejak lemahnya perlindungan terhadap anak yang ada di Indonesia terus terjadi. Kasus pelecehan seksual terhadap anak, kasus perdagangan anak (trafficking), dan kasus phedofilia sudah menjadi penyakit dibeberapa daerah di Indonesia. Salah satu contohnya adalah kasus phedofilia di sekolah Internasional JIS Jakarta, kasus phedofilia di Jawa Barat, menjadi sebuah indikasi bahwa betapa masih lemahnya penyelenggaraanperlindungan hukum terhadap anak. Pada posisi ini anak-anak tidak mendapatkan ketenteraman dan kenyamanan, melainkan malapetaka yang sangat mempengaruhi terhadap pertumbuhan jasmani dan rohani anak.

Kasus-kasus di atas dapat dikatakan sebagai bentuk kekerasan terhadap anak. Bentuk kekerasan terhadap anak dapat diklasifikasikan kepada beberapa hal, yaitu: bentuk kekerasan fisik, bentuk kekerasan psikis, bentuk kekerasan seksual, bentuk kekerasan ekonomi. ${ }^{25}$ Menyikapi

${ }^{24}$ Maulana Hasan Wadong, Advokasi dan Hukum Perlindungan Anak (Jakarta: Grasindo, 2000), h. 5.

${ }^{25}$ Lihat Purnama Rozak, "Kekerasan Terhadap Anak dalam Rumah Tangga Perspektif Hukum Islam” Jurnal Sawwa 9, no. 1 (Oktober 2013): h. 67-69. 
hal tersebut, pada akhirnya UNICEF merilis keumuman bentuk-bentuk kekerasan yang terjadi pada anak sesuai dengan tingkatan usianya. Adapun bentuk-bentuk kekerasan tersebut meliputi: ${ }^{26}$

Bentuk-bentuk Kekerasan pada Setiap Fase Anak

(Disadur dari Unicef. Domestic Violence Againts Women and Girl, 2000)

\begin{tabular}{ll}
\hline \multicolumn{1}{c}{ Fase } & \multicolumn{1}{c}{ Bentuk Kekerasan } \\
\hline Pralahir & Aborsi dan risiko janin ketika mengalami pemukulan fisik. \\
\hline Bayi & Pembunuhan anak, kekerasan fisik, psikologis dan seksual. \\
\hline Anak & $\begin{array}{l}\text { Pernikahan dini, kekerasan alat genital, inses, kekerasan fisik, } \\
\text { psikologis dan seksual. }\end{array}$ \\
\hline Remaja & $\begin{array}{l}\text { Pemerkosaan, pelecehan seksual di lingkungan sosial, dijadikan } \\
\text { wanita penghibur, kehamilan paksa, perdagangan remaja, } \\
\text { pembunuhan, pelecehan psikologis. }\end{array}$ \\
\hline
\end{tabular}

Munculnya kasus-kasus demikian semakin "liar" dan menggejala di tengah masyarakat. Hal ini disebabkan sebagian masyarakat, masih belum memahami bahwa fenomena tersebut merupakan bentuk dari tindak kekerasan terhadap anak yang menjadi persoalan serius dan membutuhkan penanganan secara bersama-sama. Sebab, semua bentuk dan tindak kekerasan yang diterima anak akan tersimpan dalam memori alam bawah sadar mereka dan akan terbawa hingga dewasa, bahkan sampai sepanjang hidupnya. Dampaknya adalah, setelah anak melalui fase pertumbuhan dan perkembangan, maka akan mensuplai perilaku yang agresif dan kekerasan yang serupaterhadap anak-anak.

Namun sayangnya, masyarakat kita masih banyak yang menganggap bahwa persoalan ini merupakan urusan pribadi masing-masing dalam keluarga, bukan sebagai tanggung jawab sosial dan pemerintah. Mestinya, anak-anak dipelihara, dibina dan dilindungi, bukan malah dijadikan sebagai objek perbuatan-perbuatan tak terpuji dan tercela. Praktik-praktik

${ }^{26}$ Unicef, "Domestic Violence Againts Women and Girl," 2000. Dikutip dari Lufita Tria, "Psychological Violence," 2012, http://psychologicalspot.wordpress.com/2012/02/22/ teoriHarisa."Teori Tipologi Bentuk Kekerasan Psikologis Terhadap Anak (Child) tipologi-bentukkekerasan-psikologis-terhadap-anak-child-psychological-violence, [22-02- 2012]. 
demikian, menurut Gus Dur sebagaimana dikutip Ahmad Muzakki, sama halnya dengan mengesampingkan perasaan saling memiliki (sense of belonging) dalam kehidupan secara kemanusiaan ukhuwah basyariah. ${ }^{27}$

Berdasarkan atas kejadian-kejadian tersebut di atas, maka seorang anak harus mendapatkan perhatian yang lebih seriusdari seluruh aspek kehidupannya. Sebab, dalam sebuah perjalanan kehidupan manusia, anak merupakanindividu yang masih belum matang baik secara fisik, mental maupun sosial. Akibat daribelum matangnya individu anak maka sangat dibutuhkan perlindungan penuh dari orang dewasa. Selain itu, diperlukan juga upaya dan usaha untuk membangun kesadaran masyarakat tentang perlindungan terhadap anak, walaupun pengakuan asal-usul seorang anak melewati mekanisme dan aturan yang telah ditetapkan. Menyadari akan hal tersebut, artikel ini akan membahas tentang keberpihakan dan keberfungsian hukum hukum Islam terhadap perlindungan anak.

\section{Islam dan "Keseriusannya" terhadap Hak Anak (Generasi Penerus)}

Keseriusan Islam terhadap suatu generasi (keturunan; baca anak) tidak bisa terbantahkan oleh apa pun dan siapa pun. Begitu seriusnya, Islam melalui kitab sucinya telah memberikan space tersendiri terhadap anak. Namun, sebelum lebih luas membahas tentang anak, alangkah baiknya jika menilik variatif-nya definisi tentang anak. Dalam sudut pandang kamus Bahasa Indonesia, anak merupakan "manusia yang masih kecil" atau "anak-anak yang masih kecil (belum dewasa)". ${ }^{28}$

Sementara itu dari sudut terminologi, banyak pakar yang memberikan pengertian tentang anak. Di antara pengertian-pengertian tersebut adalah keturunan yang kedua, manusia yang masih kecil, binatang yang masih kecil, pohon kecil yang tumbuh pada umbi atau rumpun tumbuhan-tumbuhan yang besar, orang yang termasuk dalam satu golongan pekerjaan (keluarga dan sebagainya), bagian yang kecil

${ }^{27}$ Ahmad Muzakki, Gus Dur: Pembaharu Pendidikan Humanis Islam Indonesia Abad 21 (Yogyakarta: Idea Press, 2013), h. 19.

${ }^{28}$ Lihat pada Depdikbud, Kamus Besar Bahasa Indonesia (Jakarta: Pusat Pembinaan dan Perkembangan Bahasa, dan Balai Pustaka, 1998), h. 31. 
(pada suatu benda), yang lebih kecil dari pada yang lain. ${ }^{29}$ Adapun dalam kontek hukum Islam dan hukum keperdataan, definisi anak erat disangkutpautkan dengan keluarga. Jika disangkutpautkan dengan keluarga, maka definisi anak sangat beragam. ${ }^{30}$ Oleh sebab itu, tidak mengherankan jika diklasifikasikan, definisi tentang anak sangat beragam dan memiliki aspek yang luas. Dengan demikian, dapat digarisbawahi jika berbagai makna terhadap anak, dapat diterjemahkan dengan berbagai sudut pandang dan pendekatan. Sehingga untuk mendekati anak secara benar dapat dilakukan melalui sistem kepentingan agama, hukum, sosial dari bidang masing-masing bidang.

Berbijak dari uraian di atas, dapat dikatakan jika pengertian anak dari berbagai cabang ilmu akan memiliki perbedaan, baik secara subtansial fungsinya, makna maupun tujuannya. Misalkan dalam kontek syariat Islam, tentang anak akan memiliki definisi yang berbeda dengan pengertian anak dalam kontek disiplin ilmu hukum, sosial, ekonomi, politik dan hankam. Dalam hal ini, Islam secara tegas memberikan batasan definisi dan selalu menyosialisasikan bahwa anak merupakan makhluk ciptaan Allah Swt yang arif dan berkedudukan mulia. Selain itu, proses penciptaan dan keberadaannya melalui berbagai dimensi serta menjadi kewenangan kehendak Allah Swt. ${ }^{31}$

"Keseriusan" Islam dalam menangani status anak semakin legitimate dengan banyaknya ayat Alquran-sebagai kitab suci dan sumber hukum

${ }^{29}$ Hilman Hadikusuma, Bahasa Hukum Indonesia (Bandung: Alumni, 1992).Lihat juga dalam Darwin Prinst, Hukum Anak Indonesia (Bandung: PT. Citra Aditya Bakti, 1997), h. 4. Lihat juga dalam Afisah Wardah Lubis, "Memahami Perkembangan Psikologi Anak dalam Rangka Implementasi Perlindungan Anak," Majalah Konvensi, LAAI, Medan, 1998. Juga dapat dilihat dalam Syakir Abdul Azhim, Membimbing Anak Terampil Berbahasa (Jakarta: Gema Insani, 2002), h. 2.

${ }^{30} \mathrm{Hal}$ ini meliputi anak kandung, anak laki-laki dan anak perempuan, anak sah dan anak tidak sah, anak sulung dan anak bungsu, anak tiri dan anak angkat, anak piara, anak pungut, anak kemenakan, anak pisang, anak sumbang (anak haram) dan sebagainya. Lebih lengkap lihat Pusat Bahasa Departemen Pendidikan Nasional, Kamus Besar Bahasa Indonesia (Jakarta: Balai Pustaka, 2002), h. 41.

${ }^{31}$ Jika dikaji secara rasional, berkenaan dengan anak maka akan diketahui jika seorang anak terbentuk dari unsur gaib yang bersifat transcendental dari proses ratifiksi sain (ilmu pengetahuan) dengan unsur-unsur ilmiah yang diambil dari nilai-nilai material alam semesta dan nilai-nilai spiritual yang diambil dari proses keyakinan (tauhid Islam). Lebih lengkap lihat pada Iman Jauhari, Advokasi Hak-Hak Anak Ditinjau dari Hukum Islam dan Peraturan Perundang-undangan, h. 46. 
ajaran Islam-yang membahas mengenai status anak. ${ }^{32}$ Sekiranya hal ini menggambarkan dan menegaskan bahwa Alquran atau akidah Islam sangat humanis, yaitu memposisikan anak sebagai mahluk yang sangat mulia, lengkap dengan "perangkat" rizkinya dan memiliki nilai plus. Munculnya hal tersebut, dalam kontek Islam merupakan hak dan kehendak mutlak dari Allah Swt. Sehingga untuk menyikapi dan menyingkap nilai transcendental dimaksud, Allah Swt pun menegaskan eksistensi dan keberadaan anak dalam bagian lain Alquran, yaitu Q.s. al-Tîn ayat 4, disebutkan bahwa, "Sesungguhnya aku ciptakan kamu manusia dalam bentuk yang sebaikbaiknya, atau semulia-mulianya". ${ }^{33}$

“Keberpihakan” Islam terhadap upaya perlindungan anak, benarbenar menjadi skala prioritas. Instrumen-instrumen yang berkaitan dengan hal tersebut seolah telah ditata dan diatur secara rapih guna mewujudkan generasi yang insan kâmil dan ber-rahmatan lil 'alâmin. Karenanya, perlindungan terhadap anak pun telah diajarkan sejak dini, yaitu dengan cara memberikan hak hidup terhadap janin yang ada di dalam perut sang ibu sebelum dilahirkan. Hal ini tergambar dalam firman Allah Q.s. al-An'âm ayat 140 .

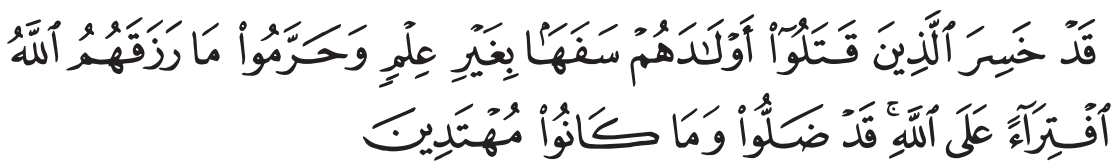

Sesungguhnya rugilah orang yang membunuh anak-anak mereka, karena kebodohan lagi tidak mengetahuidan mereka mengharamkan apa yang Allah telah rezki-kan pada mereka dengan semata-mata mengadaadakan terhadap Allah. Sesungguhnya mereka telah sesat dan tidaklah mereka mendapat petunjuk.

Secara tegas dan jelas, Islam telah memberikan petunjuk kepada umatnya untuk memberikan perlindungan terhadap anak-anaknya. Lebih

${ }^{32}$ Lebih lanjut mengenai penjelasan status anak dalam agama Islam ditegaskan dalam Q.s. al-Isra dijelaskan, bahwa, "Dan sesungguhnya telah kami muliakan anak-anak Adam. Kami angkut mereka didarat dan dilautan, kami beri mereka rezeki dari yang baik-baik dan kami lebihkan mereka dengan kelebihan yang sempurna atas kebanyakan makbluk yang telah kami ciptakan". (Q.s. al-Isra: 70).

${ }^{33}$ Lihat Q.s. al-Tîn ayat 4 
istimewa lagi, Islam tidak pernah menyebutkan dan menyinggung tentang perbedaan gender dan jenis kelamin dari seorang anak. Maksudnya, semua anak mendapatkan porsi dan hak yang sama untuk dilindungi demi perkembangan dan pertumbuhan anak secara wajar, baik dari segi fisik maupun mental dan sosialnya. Hal ini dimaksudkan, agar kelak di kemudian hari para orang tua tidak meninggalkan keturunan yang lemah. ${ }^{34}$ Oleh sebab itu, keseriusan syariat Islam terhadap perlindungan anak adalah mutlak dan merupakan ajaran suci yang sangat original berasal dari wahyu Ilahi-jauh sebelum munculnya landasan atau pondasi dari UU Nomor 23 Tahun 2002 tentang Hak Asasi Manusia (HAM) dan Konvensi PBB tentang hak-hak anak. Pengakuan dan perlindungan terhadap anak muncul seiring dengan ditasbihkannya Muhammad ibn Abdullah menjadi seorang rasul. Syariat Islam benar-benar tidak ada keraguan didalamnya dan mampu menjadi pelopor keberlangsungan hak asasi manusia di dunia.

Dalam kontek syariat Islam, anak adalah anugerah dan karunia dari Allah yang patut disyukuri kehadirannya. Ia merupakan penerus tongkat estafet keturunan yang dapat melestarikan pahala bagi orang tua sekalipun orang tua sudah meninggal. Selain itu, anak juga merupakan "bapak" masa depan yang siap memakmurkan ibu pertiwi, menjadi tentara masa depan yang siap melindungi tanah air, menjadi ilmuan yang akan menebarkan cahaya Islam dan ilmu pengetahuan ke seluruh penjuru negeri. Oleh karenanya, anak adalah titipan dan amanah dari Allah yang wajib ditangani dengan benar. ${ }^{35}$ Setiap orang tua akan selalu bekerja keras dan berupaya semaksimal mungkin-bahkan sampai ada yang menggunakan berbagai cara untuk menjaga, mengasuh dan membimbing anak-anaknya agar dapat tumbuh dan berkembang sebagaimana mestinya. ${ }^{36}$ Namun

${ }^{34} \mathrm{Hal}$ ini termaktub dalam Q.s. al-Nisa' ayat 9 yang artinya "Dan hendaklah orang-orang takut kepada Allah, bila seandainya mereka meninggalkan anak-anaknya, yang dalam keadaan lemah, yang mereka khawatirkan terhadap (kesejahteraan) mereka. Oleh sebab itu, hendaklah mereka bertakwa kepada Allah dan mengucapkan perkataan yang benar".

${ }^{35}$ Lihat M. Nipan Abdul Halim, Membahagiakan Suami Sejak Malam Pertama (Yogyakarta: Mitra Pustaka, 2005), h. 361.

${ }^{36}$ Begitu pentingnya pola asuh anak, beberapa tulisan memberikan dampak pengaruh pola asuh terhadap berbagai hal pada diri anak di antaranya Fivi Melva Diana. "Hubungan Pola Asuh dengan Status Gizi Anak Batita di Kecamatan Kuranji Kelurahan Pasar Ambacang 
seringkali, harapan tersebut tidak berbanding lurus dengan realitasnya, entah karena hal ini disebabkan oleh pola komunikasi yang keliru antara anak dengan orang tua, atau juga karena minimnya pengetahuan orang tua untuk membina anak-anaknya. Sehingga tidak jarang terlihat kejadiankejadian tentang pengasuhan dan pembinaan anak yang berujung pada kasus hukum.

Menyikapi hal tersebut, mestinya para orang tua harus memahami hakikat dan filosofi tentang eksistensi anak. Jangan sampai orang tua salah kaprah memaknai kehadiran seorang anak dari sisi biologis semata. Mestinya lebih dari itu, yakni anak adalah anugerah, amanah dan titipan Ilahi yang harus dijaga dan dipelihara dengan landasan ilmu agama dan ilmu-ilmu umum. Dengan demikian eksistensi anak akan selalu tetap terjaga dan terpelihara sesuai dengan porsinya. Merespon hal ini, dengan mengacu pada Alquran sebagai sumber hukum Islam tertinggi, telah menyebutkan beberapa istilah berkaitan dengan eksistensi anak. Adapun anak dapat diistilahkan sebagai perhiasan atau kesenangan, ${ }^{37}$ anak juga

Kota Padang tahun 2004." Jurnal Kesehatan Masyarakat Andalas 1, no. 1 (2006): h. 19-23. Siti Aisyah. "Pengaruh Pola Asuh Orang Tua Terhadap Tingkat Agresivitas Anak." Jurnal medtek 2, no. 1 (2010): h. 26-53. Muhamad Asrar, Hamam Hadi, dan Dradjat Boediman. "Pola Asuh, Pola Makan, Asupan Zat Gizi dan Hubungannya dengan Status Gizi Anak Balita Masyarakat Suku Nuaulu di Kecamatan Amahai Kabupaten Maluku Tengah Provinsi Maluku." Jurnal Gizi Klinik Indonesia 6, no. 2 (2009): h. 84-94. Yuhanda Safitri, dan Eny Hidayati. "Hubungan Antara Pola Asuh Orang Tua dengan Tingkat Depresi Remaja di SMK 10 November Semarang." Jurnal Keperawatan Jiwa 1, no. 1 (2013). Joko Tri Suharsono, Aris Fitriyani, dan Arif Setyo Upoyo. "Hubungan Pola Asuh Orang Tua Terhadap Kemampuan Sosialisasi pada Anak Prasekolah di TK Pertiwi Purwokerto Utara." Jurnal Keperawatan Soedirman 4, no. 3 (2009): h. 112-118. Luthfiah Nur Aini. "Hubungan Pola Asuh Orang Tua dengan Kenakalan Remaja di RW V Kelurahan Sidokare Kecamatan Sidoarjo.” Jurnal Keperawatan dan Kebidanan 6, no. 1 (2017). Nisha Pramawaty, dan Elis Hartati. "Hubungan Pola Asuh Orang Tua dengan Konsep Diri Anak Usia Sekolah (10-12 Tahun).” Jurnal Keperawatan Diponegoro 1, no. 1 (2012): h. 87-92. N. L. P. Y. Sanjiwani, dan I. GAPW Budisetyani. "Pola Asuh Permisif Ibu dan Perilaku Merokok pada Remaja Laki-Laki di SMA Negeri 1 Semarapura.” Jurnal Psikologi Udayana 1, no. 2 (2014): h. 344-352. Ika Fadilah Achmad, Lutfatul Latifah, dan Dewi Natalia Husadayanti. "Hubungan Tipe Pola Asuh Orang Tua dengan Emotional Quotient (EQ) pada Anak Usia Prasekolah (3-5 Tahun) di TK Islam al-Fattaah Sumampir Purwokerto Utara." Jurnal Keperawatan Soedirman 5, no. 1 (2010): h. 47-57. Kustiah Sunarty. "Implementasi Model Pola Asuh Orangtua untuk Meningkatkan Kemandirian Anak." Journal Of Educational Science and Technology 1, no. 1 (2015): h. 1-93.

${ }^{37} \mathrm{Hal}$ ini termaktub dalam Firman Allah Swt dalam Q.s. al-Kahfi ayat 46, "Harta dan anak-anak adalah perhiasan kehidupan dunia tetapi amalan-amalan yang kekal lagi saleh adalah lebih baik pahalanya di sisi Tuhanmu serta lebih baik untuk menjadi harapan." 
sewaktu-waktu dapat berubah menjadi musuh. ${ }^{38}$ Lebih membahayakan lagi anak pun sewaktu-waktu dapat berubah menjadi fitnah ${ }^{39}$ bagi keluarga dan orang tuanya. Di samping eksistensi anak sebagai amanah ${ }^{40}$ juga dapat menjadi penenteram dan penyejuk hati ${ }^{41}$ bagi orang tuanya-inilah yang menjadi idaman dan harapan dari banyak orang tua.

Berkaitan dengan kegiatan perlindungan anak, Islam sangat serius membahas tentang eksistensi seorang anak. Sampai-sampai Alquran pun memprediksikan jika anak yang pada dasarnya sebagai amanah, sewaktu-waktu dapat berubah menjadi sebuah petaka, yaitu menimbulkan permusuhan dan fitnah. Oleh sebab itu, jangan sampai ikhtiar yang dilakukan orang tua berubah dan berbalik arah, sehingga dapat membawa akibat hukum, baik dalam kaitannya dengan hukum tertulis maupun hukum tidak tertulis.

\section{Hukum Islam: Sebuah Solusi "Final” Perlindungan Terhadap Hak- hak Anak}

Hukum Islam memiliki prinsip dan nilai dasar yang sangat istimewa. Hukum Islam menaruh perhatian yang sangat ekstra terhadap hak-hak manusia-tidak memandang, kecil, besar, dewasa maupun tua-hukum Islam lebih bersifat komprehensif dan komplek. Dalam konteks perlindungan anak, hukum Islam memiliki perspektif lebih mendalam "ketimbang" hukum konvensional pada umumnya. Dalam hal perlindungan anak, hukum positif-terutama yang berlaku di Indonesia-hanya mengatur

${ }^{38} \mathrm{Hal}$ ini tergambar dalam Q.s. al-Taghabun ayat 14 yang artinya "Hai orang-orang mukmin, Sesungguhnya di antara isteri-isterimu dan anak-anakmu ada yang menjadi musuh bagimu. Maka berhati-hatilah kamu terhadap mereka dan jika kamu memaafkan dan tidak memarahi serta mengampuni (mereka) Maka Sesungguhnya Allah Maha Pengampun lagi Maha Penyayang."

${ }^{39} \mathrm{Hal}$ ini terdapat dalam Q.s. al-Taghabun ayat 15 yang artinya "Sesungguhnya hartamu dan anak-anakmu hanyalah cobaan (bagimu), dan disisi Allah-lah pahala yang besar."

${ }^{40}$ Lihat Q.s. al-Anfal ayat 27-28, yang artinya: (27) Hai orang-orang yang beriman, janganlah kamu mengkhianati Allah dan Rasul (Muhammad) dan (juga) janganlah kamu mengkhianati amanat-amanat yang dipercayakan kepadamu, sedang kamu mengetahui. (28) Dan ketahuilah, bahwa hartamu dan anak-anakmu itu hanyalah sebagai cobaan dan Sesungguhnya di sisi Allah-lah pahala yang besar.

${ }^{41} \mathrm{Hal}$ ini dapat disimak dalam Q.s.al-Furqan ayat 74, yang artinya "Dan orang orang yang berkata: "Ya Tuhan Kami, anugrahkanlah kepada Kami isteri-isteri Kami dan keturunan Kami sebagai penyenang hati (Kami), dan Jadikanlah Kami imam bagi orang-orang yang bertakwa." 
seputar pemeliharaan orang tua (alimentasi) terhadap anak, pengakuan anak, pengesahan anak. ${ }^{42}$ Mengenai indikator tentang hak dan kewajiban anak dalam hukum positif tidak dibreakdownkan secara detail. Berbeda dengan urusan perlindungan anak dalam konteks Islam.

Berkaitan dengan indikator tentang perlindungan terhadap hakhak anak, hukum Islam telah membahasnya dengan detail. Pembahasan mengenai perlindungan terhadap anak, diawali dengan cara mempersiapkan anak sejak dalam kandungan hingga dewasa. Bahkan, untuk mengantisipasi perilaku-perilaku yang dapat berakibat pada hukum, terdapat anjuran dan nasehat tentang kriteria memilih pasangan hidup yang lebih baik. Selain itu, mengungkapkan juga jaminan keberlangsungan hidup, jaminan kesehatan dan tuntunan penyambutan kelahiran jabang bayi, ${ }^{43}$ pensyariatan al-hadlânah (pengasuhan anak), jaminan beragama dan mendapatkan pendidikan, anjuran menyusui dengan air susu ibu kandung, kewajiban nafkah ayah bagi anak dan melindungi anak dari perilaku tercela dan perlakuan salah.

${ }^{42}$ Isyana K. Konoras, "Perlindungan Hukum Terhadap Anak Diluar Nikah di Indonesia," Jurnal Hukum Unsrat, Edisi Khusus I, no. 2 (Juni 2013): h. 44. Bandingkan dengan Instrumen Internasional HAM yakni Universal Declaration of Human Right (Deklarasi Universal HAM/ DUHAM) yang mengatur sejumlah ketentuan mengenai hak untuk hidup dan hak anak. Di dalam Pasal 1 dijelaskan bahwa "All human being are born free and equal in dignity and rights. They are endowed with reason and conscience and should act towards one another in a spirit of brotherhood". Dalam Pasal 3 bahwa "Everyone has the right to life, liberty and security of person". Dalam Pasal 25 ayat (2) bahwa "Motherhood and childhood are entitled to special care and assistance. All children, whether born in or wedlock, shall enjoy the same social protection". Lebih lengkap lihat "Universal Declaration of Human Right," t.t., http://www.ohchr.org/EN/UDHR/ Pages/ Language.aspx?LangID=inz.

${ }_{43}$ Berupa anjuran mengadzani anak yang baru lahir, meski masalah adzan di telinga bayi ini adalah masalah khilafiyah, ada sebagian yang memandangnya mustahab dan sunnah, dimana sebenarnya cukup banyak ulama yang berpendapat sunnahnya adzan di telinga bayi. Berkaitan dengan adzan di telinga bayi, Wahbah al-Zuhaily, seorang ulama ahli fiqih kontemporer abad 20 mengatakan bahwa selain digunakan untuk salat, adzan juga dikumandangkan pada beberapa even kejadian lainnya. Lebih lengkap lihat Wahbah al-Zuhaily, al-Figh al-Islámy wa Adillatuh (Bayrût: Dár al-Fikr, 1989). Adapun hadis yang menguatkan adzan di telinga bayi adalah $A b u$ Rafi meriwayatkan: Aku melihat Rasulullah Saw mengadzani telinga al-Hasan ketika dilahirkan oleh Fatimah. (H.r. Abu Daud, al-Tirmizy dan al-Hakim). Mengenai hadis ini, al-Imam al-Hakim menyebutkan hadis shahih. Selain itu, al-Imam al-Nawawi juga termasuk menshahihkan hadis ini sebagaimana tertuang di dalam kitab al-Majmu' Syarah al-Muhadzdzab. Lebih lengkap lihat Al-Imam al-Nawawi, Al-Majmu' Syarah Al-Muhzdzdzab, 9, t.t., h. 348. Sementara itu, berkaitan dengan anjuran memberikan nama yang baik juga telah diatur. Hal ini dapat dilihat dalam hadis nabi yang berbunyi "Sesungguhnya mereka memberikan nama (pada anak-anak mereka) dengan nama-nama para nabi dan orang-orang sholih" (H.r. Muslim). Begitu juga dengan anjuran khitan dan mencukur rambut kepala. 
Selanjutnya, kedudukan anak dalam perspektif Islam sangatlah istimewa, yaitu anak merupakan titipan Allah kepada orang tua, masyarakat, bangsa dan Negara, sebagai pewaris dari ajaran Islam (wahyu Allah Swt) yang kelak akan memakmurkan dunia sebagai rạmatan lil âlamîn. ${ }^{44}$ Adapun "status" tersebut pada dasarnya mengkhabarkan tentang pemberian hak, sehingga melahirkan hak anak yang kemudian harus diyakini dan diamalkan. Upaya ini merupakan amalan yang mesti diimplementasikan oleh orang tua, masyarakat, bangsa dan negara terhadap anak. Orang tua, masyarakat, bangsa bahkan negara sekalipun tidak boleh ragu dan takut tertimpa "musibah" berupa kemiskinan dan lain sebagainya, jika intens mengimplementasikan perlindungan terhadap anakanak. Karena Allah telah menjamin dan akan memberikan kemudahan, baik berupa kelapangan rizki atau apapun bagi mereka yang melindungi anak-anak. ${ }^{45}$ Artinya, bagi umat Islam pada dasarnya tidak ada alasan untuk tidak memelihara, melindungi hak-hak anak. Jika masih saja dipungkiri, sama halnya mengesampingkan sumber hukum Islam tertinggi, yaitu Alquran.

Berkenaan dengan hak, Hasbi ash Shiddieqy mengklasifikasikan hak dalam dua makna yang paling asasi. ${ }^{46}$ Sedangkan hak menurut Satjipto Rahardjo dalam Marwan Mas, disebutkan sebagai sebentuk kekuasaan yang diberikan oleh hukum kepada seseorang dengan tujuan untuk melindungi kepentingan seseorang tersebut. ${ }^{47}$ Pada dasarnya, kata hak berasal dari bahasa Arab, "haq" yang secara etimologi memiliki beberapa

${ }^{44}$ Iman Jauhari, Advokasi Hak-Hak Anak Ditinjau dari Hukum Islam dan Peraturan Perundang-undangan, h. 50.

${ }^{45}$ Berkaitan dengan janji Allah tentang perlindungan anak telah disebutkan dalam Q.s. al-Isra ayat 31, yang artinya "Dan janganlah kamu membunuh anak-anak karena takut kemiskinan. Kamilah yang member rezki kepada mereka dan juga kepada kamu. Sesungguhnya membunuh mereka adalah suatu dosa yang besar".

${ }^{46}$ Dalam pandangan TM. Hasbi Ash Shiddiqie hak adalah: Pertama hak merupakan sekumpulan kaidah dan masih yang mengatur dasar-dasar yang harus ditaati dalam hubungan manusia sesama manusia, baik mengenai orang, maupun mengenai harta. Dalam pengertian yang pertama kali, hak sama dengan makna hukum dalam istilah sarjana ushul. Inilah yang dikehendaki di waktu mengatakan al-haqqul madâniyah. Kedua, hak merupakan kekuasaan menguasai sesuatu atau sesuatu wajib atas seseorang bagi selainnya. Lebih lengkap lihat pada Tengku Muhammad Hasbi ash Shiddieqy, Pengantar Fiqh Mu'amalah (Semarang: PT. Pustaka Rizki Putra, 1997), h. 121.

${ }^{47}$ Marwan Mas, Pengantar Ilmu Hukum (Bogor: Ghalia Indonesia, 2011), h. 30. 
makna, ${ }^{48}$ yaitu kepastian atau ketetapan, ${ }^{49}$ kebenaran, ${ }^{50}$ menetapkan atau menjelaskan. ${ }^{51}$

Oleh sebab itu, tidak mengherankan jika kemudian muncul perbedaan pandangan mengenai hak dalam perspektif hukum Islam dan hukum modern. Dalam kontek Islam, hak dipandang sangat komprehensif dan tidak parsial. Hak merupakan aturan-aturan yang ditetapkan syara' dan mengandung nilai moral, yang tujuannya untuk memelihara kemaslahatan kehidupan manusia di dunia dan akhirat. Sedangkan dalam pandangan hukum modern, hak merupakan kekuasaan yang melekat pada setiap manusia yang dapat digunakan secara bebas tanpa harus memperhatikan hak dan kepentingan pihak lain. ${ }^{52}$

Sekali lagi, Islam tidak pernah membeda-bedakan mengenai hak. Namun, Islam sangat menentang terhadap perbedaan hak antara lakilaki dan perempuan dalam tata kehidupan masyarakat. Dalam konteks Islam, terdapat konsep yang sangat berimbang mengenai pemberian tugas, peran, dan tanggungjawab antara perempuan dan laki-laki, baik dalam keluarga (ruang domestik) maupun di masyarakat (ruang publik) didasarkan pada wahyu Allah dan tidak semuanya merupakan produk budaya. Peran bukan ditentukan oleh budaya, melainkan wahyu Allah yang telah dicontohkan pelaksanaannya oleh Nabi Muhammad Saw. Ini menunjukkan bahwa Islam adalah agama wahyu yang ajaran-ajarannya ditentukan tidak berdasarkan konsensus sosial atau budaya masyarakat tertentu tetapi berdasarkan wahyu Allah. ${ }^{53}$

Sementara itu, dalam menegaskan hal tersebut di atas, Alquran telah menjelaskan jika dalam kehidupan sosial antara laki-laki dan wanita

${ }^{48}$ Ghufron Mas'adi, Fiqh Muamalah Kontekstual, (Jakarta: PT Raja Grafindo Persada, 2002), h. 31-32

${ }^{49}$ Lihat Q.s. Yasin ayat 7 "Sesungguhnya telah pasti Berlaku Perkataan (ketentuan Allah) terhadap kebanyakan mereka, kerena mereka tidak beriman”.

${ }^{50}$ Lihat Q.s. Yunus ayat 35; "Katakanlah: "Apakah di antara sekutu-sekutumu ada yang menunjuki kepada kebenaran?" Katakanlah "Allah-lah yang menunjuki kepada kebenaran".

${ }^{51}$ Q.s. al-Anfal, ayat 8; "Agar Allah menetapkan yang hak (Islam) dan membatalkan yang batil (syirik) walaupun orang-orang yang berdosa (musyrik) itu tidak menyukainya."

${ }^{52}$ Siti Mujibatun, Pengantar Figh Muamalah (Semarang: Lembaga Studi Sosial dan Agama, 2012), h. 57.

${ }^{53}$ Adian Husaini, "RUU Kesetaraan Gender Perspektif Islam," 22 Maret 2012, h. 23. 
mempunyai peran dan tugas masing-masing. ${ }^{54}$ Oleh sebab itu, pada hakikatnya segala hak yang melekat pada manusia bersumber dari hakhak Allah. Untuk itu, setiap manusia harus menggunakan haknya sesuai dengan ketetapan syara' yaitu untuk mewujudkan kemaslahatan pribadi dan kemaslahatan publik (umum). ${ }^{55}$

Hak asasi anak manusia dalam dimensi Islam memiliki cakupan yang sangat luas, mulai dari hak yang bersifat pribadi sampai ajaran kehidupan yang bersifat sosial. Oleh karena itu, dalam konteks masyarakat Indonesia yang sangat beragam dan multikultural, posisi perlindungan terhadap hak-hak anak sebagai calon penerus generasi belum secara utuh "tersentuh" oleh keluarga, masyarakat, bangsa dan negara. Padahal jika hak-hak anak diperhatikan dan dilindungi oleh hukum-baik hukum Islam maupun hukum positif-maka akan memberikan pengaruh terhadap bangsa ini. Menyikapi hal ini, Abdur Rozak Hussein menyatakan, jika benih anak dalam masyarakat itu baik maka sudah pasti masyarakat terbentuk menjadi masyarakat yang baik pula. Selain itu, dalam Islam juga dinyatakan bahwa anak-anak merupakan benih yang akan tumbuh untuk membentuk masyarakat di masa yang akan datang. ${ }^{56}$ Oleh sebab itu, orang tua, masyarakat, bangsa dan negara memiliki kewajiban untuk menunaikan hak-hak anak. Namun demikian, dalam skala yang lebih kecil-orangtua sebagai elemen utama sebagai pelindung anak-anaknya-memiliki kewajiban dan tanggung jawab dalam menunaikan perlindungan terhadap hak-hak anak. Selanjutnya, agar supaya anak-anak tidak terperosok kedalam jurang kedzaliman, karena telah melalaikan dan mengesampingkan hak-hak anak, maka orang tua sebagai benteng utama perlindungan bagi anak mestinya berkewajiban memperhatikan hak-hak anak sebelum lahir dan setelah lahir.

${ }^{54}$ Baharuddin Lopa, Al-Qur'an dan Hak Asasi Manusia (Yogyakarta: Dana Bhakti Prima Yasa, 1996), h. 75.

55 Siti Mujibatun, Pengantar Figh Muamalah, h. 57-58.

${ }^{56}$ Abdul Rozak Husein, Hak-Hak Anak dalam Islam (Jakarta: Fikahati, Aneska, 1992), h. 19. 


\section{Hak Anak Sebelum Lahir}

Perhatian Islam terhadap anak sebagai calon generasi penerus bukan hanya sekadar retorika belaka. Namun diwujudkan dalam bentuk perhatian nyata dan ril, yaitu dimulai sejak dari dalam rahim ibu atau masih dalam bentuk janin. Dengan kata lain, Islam memperhatikan masalah anak sejak sebelum berbentuk. Upaya perlindungan janin sejak dalam rahim ibunya merupakan bentuk perlindungan jasmaniah maupun rohaniyah untuk sebuah janin agar kelak dapat tumbuh dan berkembang dengan baik sampai lahir kedunia dengan sempurna. ${ }^{57}$ Keberpihakan Islam terhadap perlindungan anak sejak dalam janin, pada akhirnya diakui dan dijadikan "standard" oleh para pakar psikologi ${ }^{58}$ perkembangan anak. Terdapat sebuah kesepakatan jika perkembangan anak itu pada dasarnya dipengaruhi oleh kondisi atau keadaan sejak pra-natal.

Menyikapi hal tersebut, hukum Islam secara tegas telah memperhatikan dan berupaya untuk melindungi keberadaan hak-hak anak, sejak sebelum dilahirkan (baca; janin). Begitu perhatiannya, Allah pundengan segala ke-Maha Pemurahan-Nya-turut "andil" dalam "menjaga" dan melindungi ibu hamil. Adapun caranya adalah memberikan keringanan terhadap pelaksanaan ibadah wajib, seperti kewajiban berpuasa pada bulan Ramadan, jika dengan mengerjakannya dapat menimbulkan madharat terhadap janin atau bayi (sesudah lahir). Akan tetapi dia wajib menggantinya setelah illat-nya itu hilang. ${ }^{59} \mathrm{Di}$ sinilah terlihat jika hukum Islam sangat memuliakan keberadaan seorang anak. Hak anak sebelum

${ }^{57}$ Abu Hadiyan Shafiyarrahman, Hak-Hak Anak dalam Syariat Islam (Yogyakarta: AlManar, 2003), h. 25.

${ }^{58}$ Dalam hal ini Monk, mengamini dan menyepakati jika perkembangan anak sesudah dilahirkan dipengaruhi pengaruhi oleh kondisi pra-natal. Adapun hal yang mempengaruhi tersebut adalah (1) Pengaruh dari lingkungan (faktor ekstern, ketegangan, kebiasaan subyektif, ketegangan emosi, tahayyul); (2) Sikap dari seorang Ibu. Lebih lengkap lihatF.J. Monks, Psikologi Perkembangan (Yogyakarta: UGM Press, 1985), h. 49-54. Hal senada juga dikatakan oleh Hurlock, bahwa pada periode pra-natal merupakan masa yang mengandung banyak bahaya, baik fisik maupun psikologis. Meskipun tidak dapat di klaim bahwa periode ini merupakan periode yang paling berbahaya, tetapi jelas bahwa periode ini merupakan masa dimana bahaya-bahaya lingkungan atau bahaya psikologis dapat sangat mempengaruhi pola perkembangan selanjutnya atau bahkan dapat mengakhiri suatu perkembangan. Lebih lengkap lihat Elizabeth B Hurlock, Psikologi Perkembangan (Jakarta: Penerbit Erlangga, t.t.), h. 28.

${ }^{59}$ Abdurrazaq Husein, Hak Anak dalam Islam (Bandung: Pustaka, 2001), h. 20. 
lahirpun mendapatkan porsi untuk dilindungi dan dijaga dari segala bentuk tindakan tercela agar dapat tumbuh dan berkembang dengan sempurna.

\section{Hak Anak Setelah Lahir}

Masa bayi merupakan fase kehidupan yang sangat penting (vital). Sebab, kondisi fisik dan mental bayi akan menjadi dasar atau pondasi yang kokoh terhadap perkembangan dan pertumbuhan selanjutnya. ${ }^{60}$ Pasca kelahiran, tidak lama berselang bayi akan merespon apa yang ada di sekitarnya dan mulai menunjukkan tingkah laku serta karakteristik yang khas.

Syariat Islampun sangat serius dalam memberikan perlindungan kepada anak. Hal ini dibuktikan dengan pemberian hak-hak yang begitu banyak demi menjamin pertumbuhan dan perkembangan anak ${ }^{61}$ hingga menjadi manusia yang sempurna, baik jasmani maupun rohani. Orang tua, masyarakat, bangsa dan negara memiliki tugas berat dalam melindungi hak-hak anak pasca kelahirannya. Adapun hak-hak anak yang perlu dilindungi secara berasama-sama oleh orang tua, masyarakat, bangsa dan negara, di antaranya adalah:

\section{a. Hak untuk hidup}

Sejarah kelam tentang kehidupan umat manusia pada masa Arab Jahiliyah $^{62}$ tidak akan pernah terulang lagi pasca datangnya Islam di

${ }^{60}$ Katini Kartono, Psikologi Anak (Bandung: Mandar Maju, 1995), h. 78.

${ }^{61}$ Pertumbuhan merupakan perubahan secara fisiologis sebagai hasil dari proses pematangan fungsi-fungsi fisik yang berlangsung secara normal pada anak yang sehat dalam passage (peredaran waktu tertentu). Sedangkan perkembangan adalah perubahan psiko fisik sebagai hasil dari proses pmatangan fungsi-fungsi psikis dan fisik pada anak, ditunjang oleh faktor lingkungan dan proses belajar dalam passage waktu tertentu menuju kedewasaan. Lihat dalam Katini Kartono, h. 18, 21.

${ }^{62}$ Menurut Mufassir al-Rozi, orang Arab (masa Jahiliyah) sering membunuh anak perempuan mereka karena beranggapan bahwa mereka tidak mampu bekerja mencari harta yang hanya bisa dilakukan oleh anak laki-laki. Hal ini karena keberanian orang arab untuk merampas harta dan menyerang orang lain. Lebih lengkap lihat pada Muhammad al-Razi, Tafsir al-Fakhr al-Razi, vol. 10, 9 (Bayrut, Libanon: Dar al-Fikr, 1994), h. 198. Tidak hanya penghapusan terhadap hak hidup bagi bayi perempuan, bahkan pada masa Jahiliyah peperangan antar suku sering terjadi seolah tidak akan berakhir. Lebih lengkap lihat Badri Yatim, Sejarah Peradaban Islam, Cet X (Jakarta: PT Raja Grafindo Persada, 2000), h. 11. 
muka bumi ini. Semua bayi yang lahir, baik laki-laki maupun perempuan diakui hak-haknya untuk hidup. Dalam syariat Islam, hak hidup seseorang adalah fitrah dan menjadi hak mutlak Allah Swt. Artinya, tidak ada suatu makhluk apapun yang dapat mengganggu kehidupan manusia (baca; memberikan kematian kepada yang lain). Masalah hidup dan kehidupam hanyalah milik Allah, tidak ada perubahan dan pergantian bagi sunnah (ketetapan Allah). ${ }^{63}$ Oleh sebab itu, Islam sangat melarang pembunuhan terhadap anak dengan alasan apapun,baik karena kemiskinan atau alasan lain. Sehingga Islam menyuruh seluruh umat manusia agar senantiasa menjaga hak hidup anak kecil atau bayi, baik yang orang tuanya muslim ataupun non muslim, makanya dalam setiap pertempuran, Islam melarang seluruh kaum muslim membunuh kaum hawa dan anak-anak. ${ }^{64}$

Berdasarkan uraian diatas kiranya sangat jelas, jika Islam include di dalamnya hukum Islam sangat memperhatikan hak hidup dari seorang anak. Hal ini ditegaskan dalam Q.s. Al-An'am ayat 15, yang artinya: Dan janganlah kamu membunuh anak-anak kamu karena takut kemiskinan, kami akan memberi rizki kepadamu dan kepada mereka. Sangatlah jelas bahwa dalam setiap jiwa terdapat hak prinsipil untuk bisa hidup sebagaimana mestinya. Prinsip kemanusiaan ini juga menjadi basis dari relasi sosial dalam kehidupan manusia. Itu sebabnya seseorang tidak boleh bertindak zalim terhadap yang lain. Sebaliknya setiap orang harus saling berbuat baik dan membantu satu sama lain.

\section{b. Hak Pengakuan Silsilah dan Keturunan}

Setiap anak yang lahir ke dunia ini pada dasarnya ingin mendapatkan hak yang sama, yaitu pengakuan dalam silsilah dan keturunan. Selain hak keberlangsungan untuk hidup, ${ }^{65}$ hak memperoleh pengakuan dalam silsilah merupakan hal yang sangat penting karena

${ }^{63}$ Kamil Musa, Anak Perempuan dalam Konsep IslamAnak Perempuan dalam Konsep Islam (Jakarta: CV. Firdaus, 1994), h. 14.

${ }^{64}$ Abdurrazaq Husein, Hak Anak dalam Islam, h. 22.

${ }^{65}$ Islam menyuruh seluruh umat manusia agar senantiasa menjaga hak hidup anak kecil atau bayi, baik yang orang tuanya muslim ataupun non muslim, makanya dalam setiap pertempuran, Islam melarang seluruh kaum muslim membunuh kaum hawa dan anak-anak. Lihat Abdurrazaq Husein, h. 22. 
akan berpengaruh besar bagi kehidupan selanjutnya. Seorang anak yang dinisbatkan kepada bapaknya akan menciptakan legalitas ${ }^{66}$ akan sebuah pengakuan dari masyarakat. Hal ini akan berdampak pada jiwa (psikis) seorang anak tentang rasa aman dan tenang ${ }^{67}$ di dalam lingkungannya. Berkaitan dengan legitimasi nasab, silsilah dan keturunan telah di tegaskan oleh Allah swt dalam firman Allah yang artinya: Panggilah mereka (anak-anak angkat itu) dengan (memakai) nama bapak-bapak mereka. Itulah yang lebih adil pada sisi Allah, dan jika kamu tidak mengetahui bapak-bapak mereka, maka (panggilah mereka sebagai) saudara-saudaramu seagama dan maula-maulamu. Dan tidak ada dosa atasmu terhadap apa yang kamu khilaf padanya, tetapi (yang ada dosanya) apa yang disengaja oleh hatimu. Dan adalah Allah Maha Pengampun lagi Maha Penyayang. ${ }^{68}$

Secara legal, ayat tersebut dapat dijadikan landasan hukum untuk memberikan penguatan kepada orangtua, masyarakat, bangsa dan negara untuk mengakui hak silsilah dan keturunan dari seorang anak. Merespon hal tersebut, tidak mengherankan jika pada akhirnya negara mewujudkan dan membuktikannya dengan pemberian akta kelahiran sebagai bukti bukti pengakuan negara terhadap status kewarganegaraannya. Selain itu, dengan menggunakan akta kelahiran anak akan mendapatkan kepastian hukun tentang keberadaan orang tuanya. Selembar surat ini akan terus diperlukan sampai ia dewasa kelak. ${ }^{69}$ Dengan demikian dapat dikatakan bahwa pengakuan silsilah dan keturunan dari seorang anak sangatlah penting untuk keberlangsungan kehidupan anak di lingkungan, masyarakat dan negara. Sebelum negara mengaplikasikan hak anak tentang silsilah dan keturunan, Islam telah lebih dulu menegaskan jika silsilah dan keturunan sangat penting dalam kehidupan untuk sebuah legalitas dan kedudukan seorang anak.

${ }^{66}$ Pengakuan dalam silsilah dan keturunan disebut juga dengan keabsahan. Keabsahan adalah sentral bagi pembentukan keluarga dalam Islam. Setiap anak muslim mempunyai hak atas legitimasi (keabsahan), yakni dipanggil menurut nama ayah yang diketahui. Lebih lengkap lihat Ahmad Abdullah Assegaf, Islam dan KB (Jakarta: Lentera Basritama, 1997), h. 38.

${ }^{67}$ Abdurrazaq Husein, Hak Anak dalam Islam, h. 24. Lihat juga dalam Abu Hadiyan Shafiyarrahman, Hak-Hak Anak dalam Syariat Islam, h. 48.

${ }^{68}$ Lihat Q.s. al-Ahzab ayat 5.

${ }^{69}$ Marfu’ah Panji Astuti, "Pelanggaran Hak-Hak Anak di Sekitar Kita," Nakita, 26 Juli 2003. 


\section{c. Hak Mendapat Nama yang Baik}

Berkaitan dengan nama, seorang anak berhak menerima nama yang baik dari orang tuanya. Pemberian nama yang baik terhadap anak pada dasarnya berkaitan erat dengan pendidikan dan sebuah pengharapan dari kedua orang tuanya. Selain itu, nama adalah identitas dari seseorang yang akan selalu melekat dan berhubungan erat dengan dirinya, baik semasa dia hidup maupun sesudah mati. Nama itu, sendiri juga merupakan tali pengikat yang amat kuat dengan semua tali keturunannya. ${ }^{70}$

Dalam kontek Islam, pemberian nama yang baik adalah kewajiban bagi orang tuanya. Sebab, nama dalam perspektif Islam memiliki pengaruh besar dan arti penting bagi empunya nama. Hal ini sesuai dengan sabda nabi yang artinya: "Sesungguhnya kamu sekalian (kelak) pada hari kiamat akan dipanggil dengan nama kalian dan nama bapak-bapak kalian. Maka perbaguslah nama-nama kalian." (H.r. Abû Dawud). ${ }^{71}$ Dalam Islam sangat jelas, jika nama (baca; pemberian nama) akan menjadi abadi. Tidak hanya berlaku di dunia, namun sampai kelak di akhirat.

Sementara itu dalam perspektif psikolog, nama akan memberikan kebanggaan dan pengaruh yang kuat terhadap anak. Sehingga, anak akan tersugesti untuk berprilaku sesuai dengan makna yang melekat dan menyatu dalam dirinya. ${ }^{72}$ Melihat hal demikian, mestinya orang tua memberikan nama-nama yang baik kepada anak-anaknya. Sebab hal ini akan berpengaruh dan menentukan kepribadian anak dimasa depan. Berdasarkan teori labelling (penamaan), maka nama seseorang berpengaruh terhadap perilaku. Menurut teori ini, memiliki pengaruh kemungkinan seorang menjadi jahat karena masyarakat menamainya sebagai penjahat. ${ }^{73}$ Dari sinilah timbul persepsi bahwa nama dapat membentuk konsep dirisadar atau tidak sadar orang akan didorong untuk memenuhi image yang

${ }^{70}$ Abdurrazaq Husein, Hak Anak dalam Islam, h. 27.

71 Abû Dawud Sulaiman, Sunan Abi Dawud, 3 (Bayrut, Libanon: al-Kutub al-Islamiyah, 1996), h. 292. Hadits Ke 4948.

72 Wahjoetomo, Perguruan Tinggi Pesantren; Pendidikan Alternatif Masa Depan (Jakarta: Gema Insani Press, 1997), h. 32-33.

73 Jalaluddin Rahmad, Islam Aktual: Refleksi Sosial Seorang Cendekiawan Muslim, Cet.XIII (Bandung: Mizan, 2001), h. 185. Lihat juga dalam M.A Asyhari dan Ummu Khoiroh, Kupinang Engkau Secara Islami (Surabaya: Putra Pelajar, 2001), h. 175. 
melekat dalam namanya. Oleh sebab itu, menurut ajaran Islam nama adalah doa ${ }^{74}$ yang akan memberikan rasa kebanggaan, rasa sosial dan rasa penghormatan. Karenanya Islam menganjurkan untuk menghindari pemberian nama yang tidak baik kepada anak-anaknya. ${ }^{75}$ Dengan kata lain, nama yang melekat pada anak-anak akan menjadi sebuah identitas dari kepribadian orang tua dan keluarganya-melalui nama tersebut seseorang akan dapat mengidentifikasi tipe keluarganya.

\section{d. Hak Menerima Aqîqah}

Seiring dengan hak mendapatkan nama yang baik, seorang anak di dalam syariat Islam berhak untuk menerima tebusan dari orang tuanyayang populer dengan nama aqîqah. Aqiqah merupakan penyembelihan binatang atas dasar kelahiran anak, di hari ke-7 pasaca lahirnya. Pada dasarnya syariat ini menggambarkan rasa syukur dan pengungkapan rasa suka cita atas lahirnya seorang anak. Para ulama berbeda pendapat mengenai hukum mengeluarkan tebusan. Ada yang mengatakan sunah ${ }^{76}$, mustahab (dianjurkan)-namun adajuga ulama yang "mewajibkannya". ${ }^{77}$ Oleh sebab itu, bagi orang tua yang mampu tidak ada alasan lagi untuk mengaqîqahkan kelahiran anak-anaknya. Sebab, pada satu sisi aqîqah memiliki manfaat bagi hubungan batin antara orang tua dan anak, yaitu berupa wujud keikhlasan.

Dalam dimensi akidah dan perspektif Islam, pada dasarnya berkaitan dengan hak anak meliputi banyak hal. Namun dalam tulisan ini penulis tidak akan menguraikannya satu persatu. Adapun hak-hak anak yang berhasil penulis himpun adalah: (1) Hak melindungi anak ketika di dalam

${ }^{74}$ Ramayulis dkk, Pendidikan Islam dalam Rumah Tangga (Jakarta: Kalam Mulia, 2001), h. 117.

${ }^{75}$ Dalam hal ini Ibnul Qayyim al Jauziyyah dalam Adnan Hasan Shalih mengemukakan bahwa, pemberian nama yang baik akan mendorong yang mempunyai nama untuk berbuat yang baik sesuai dengan makna yang terdapat didalam namanya. Hal ini terjadi karena ia merasa malu terhadap nama yang di sandangnya bila perbuatannya tidak sesuai dengan namanya demikian. Lebih lengkap lihat Adnan HasanShalih Baharist, Tanggung Jawab Ayah terhadap Anak Laki-Laki (Jakarta: Gema Insani Press, 1996), h. 57.

${ }^{76}$ Abu Suja', Fathul Qorib Mujib (Taqrib) (Bandung: Ma’arif, t.t.), h. 63.

${ }^{77}$ Salah satu ulama yang mewajibkan adalah Adh-Dhahiriyyah dan Abu al Hasan al- Basri. Lebih lengkap lihat Kamil Musa, Anak Perempuan dalam Konsep Islam Anak Perempuan dalam Konsep Islam, h. 37. 
rahim (kandungan) Ibu; (2) Hak untuk disusui selama dua tahun; (3) Hak untuk diberi pendidikan, ajaran, pembinaan, tuntutan dan akhlak yang benar; (4) Hak untuk mewarisi harta kekayaan milik kedua orang tuanya; (5) Hak untuk mendapatkan nafkah dari orang tuanya; (6) Hak untuk mempertahankan agama dan akidahnya. ${ }^{78}$ Sementara itu, dalam pendapat lain, lebih detail disebutkan jika hak-hak anak meliputi banyak hal, yaitu: (1) Hak untuk hidup; (2) Hak mendapat nama yang baik; (3) Hakdisembelihkan aqîqahnya; (4) Hak untuk mendapatkan ASI (dua tahun); (5) Hak makan dan minum yang baik; (6) Hak diberi rizki yang baik; (7) Hak mendapatkan pendidikan agama; (8) Hak mendapatkan pendidikan salat; (9) Hak mendapat tempat tidur terpisah antara laki-laki dan perempuan; (10) Hak mendapatkan pendidikan dengan pendidikan adab yang baik; (11) Hak mendapat pengajaran yang baik; (12) Hak mendapat pengajaran Alquran; (13) Hak mendapat pendidikan dan pengajaran baca tulis; (14) Hak mendapat perawatan dan pendidikan kesehatan; (15) Hak mendapat pengajaran keterampilan Islammemberantas pengangguran; (16) Hak mendapat tempat yang baik dalam hati orang tua; (17) Hak mendapat kasih sayang. ${ }^{79}$

Berdasarkan pada uraian di atas, dapat dikatakan jika Islam benarbenar meletakkan hak anak dalam posisi yang sangat mulia. Hal ini tentu saja menggambarkan bahwa perlindungan atas hak anak dalam hukum Islam memiliki tujuan dasar untuk membangun kehidupam umat manusia yang memagah teguh ajaran Islam. Dengan kata lain, perlindungan terhadap hak-hak anak dalam perspektif hukum Islam lebih bersifat komprehensif, yaitu mengatur dan melakukan perlindungan anak sejak dalam kandungan hingga tumbuh menjadi dewasa.

Jika hukum Islam telah "berpihak" terhadap perlindungan hakhak anak, maka harus direspon secara positif oleh negara dan bangsa ini. Sebab, mayoritas penduduk bangsa ini adalah pemeluk Islamsehingga tidak ada alasan untuk menunda-nunda merealisasikan dan

${ }^{78}$ Iman Jauhari, Perlindungan Hukum terhadap Anak dalam Keluarga Poligami (Jakarta: Pustaka Bangsa Press, 2003), h. 87.

${ }^{79}$ Imran Siswandi, "Perlindungan Anak dalam Perspektif Hukum Islam dan HAM," Jurnal Al-Mawarid XI, no. 2 (Januari 2011): h. 228-232. 
mengaplikasikan hak-hak anak. Berkenaan dengan hal tersebut ada dua konsep ${ }^{80}$ kebijakan yang perlu dikembangkan oleh pemerintah dalam pembangunan yang berpihak terhadap kepentingan anak. Pertama, kebijakan pembangunan yang memberikan perhatian penting terhadap kesejahteraan ${ }^{81}$ dan perlindungan anak atau disebut "Child Meanstreaming Policy". Kedua, kebijakan pembangunan yang bersahabat dengan anak atau disebut "Child Friendly Policy" demi keutuhan tumbuh kembang anak dalam menghadapi masa depan bangsa dan negara. Karena apa yang dilakukan terhadap anak sekarang ini akan dilihat hasilnya dalam jangka waktu 20-30 tahun yang akan datang.

Hukum Islam salah satu norma yang dianut oleh masyarakat di Indonesia perlu diintensifkan untuk dijadikan salah satu piranti oleh negara dalam memberikan perlindungan terhadap anak dari bentukbentuk kekerasan dan tindak eksploitasi. Sebab, di dalam norma hukum Islam terdapat nilai transendental yang hakiki dan memiliki keunggulan dan kelebihan tersendiri. Hal ini menyebabkan para penganutnya lebih yakin jika ajaran agama dipahami dengan baik, maka akan muncul jika agama tidak menghendaki terjadinya eksploitasi sesama manusia. Selanjutnya, elastisitas hukum Islam dengan prinsip "shâlih li kulli zamân wa makân" dan prinsip "al-hukmu yadûru máallatihi wujûdan wa 'adaman" menghendaki dilakukannya analogi dan interpretasi baru sesuai dengan konteks fenomena kejahatan yang terjadi pada anak saat ini. Nilai-nilai penegakan keadilan, pencegahan kezaliman, dan perlunya kerjasama dalam mengatasi masalah-masalah sosial merupakan misi kemanusiaan yang dibawa agama. Namun demikian, nilai-nilai tersebut perlu senantiasa diaktualkan dan diinterpretasikan kembali sesuai dengan perkembangan terbaru modus kejahatan.

${ }^{80}$ Sugianto, "Menghindari Kekerasan Terhadap Anak Menurut Perspektif Undang-Undang Perlindungan Anak," Jurnal de Jure, Jurnal Syariah dan Hukum 4, no. 1 (Juli 2012): h. 67-68.

${ }^{81}$ Kesejahteraan Anak adalah suatu tata kehidupan dan penghidupan anak yang dapat menjamin pertumbuhan dan perkembangannya dengan wajar, baik secara rohani, jasmani maupun sosial. Lihat Pasal 1 angka 1 huruf a Undang-Undang No. 4 Tahun 1979 tentang Kesejahteraan Anak. 


\section{Penutup}

Berdasarkan uraian di atas dapat penulis simpulkan bahwa hukum Islam sangat berpihak terhadap perlindungan anak. Anak ditempatkan pada posisi yang sangat mulia. Perlindungan atas hak anak dalam hukum Islam memiliki tujuan dasar untuk membangun kehidupam umat manusia yang memagang teguh ajaran Islam. Hukum Islam memiliki prinsip dan nilai dasar yang sangat istimewa. Hukum Islam menaruh perhatian yang sangat ekstra terhadap hak-hak manusia-tidak memandang, kecil, besar, dewasa maupun tua-hukum Islam lebih bersifat komprehensif dan komplek.

Adapun hak-hak anak yang perlu dilindungi secara berasama-sama oleh orang tua, masyarakat, bangsa dan negara, di antaranya adalah: hak anak sebelum lahir dan hak anak sesudah lahir yang meliputi banyak hal, diantaranya hak untuk hidup, hak mendapat nama yang baik, hak disembelihkan aqîqahnya, hak untuk mendapatkan ASI (dua tahun), hak makan dan minum yang baik, hak diberi rizki yang baik, hak mendapatkan pendidikan agama, hak mendapatkan pendidikan salat, hak mendapat tempat tidur terpisah antara laki-laki dan perempuan, hak mendapatkan pendidikan dengan pendidikan adab yang baik, hak mendapat pengajaran yang baik, hak mendapat pengajaran Alquran, hak mendapat pendidikan dan pengajaran baca tulis, hak mendapat perawatan dan pendidikan kesehatan, hak mendapat pengajaran keterampilan Islam memberantas pengangguran, hak mendapat tempat yang baik dalam hati orang tua, dan hak mendapat kasih sayang.

Hukum Islam dalam kontek perlindungan anak, memiliki perspektif lebih mendalam, detail dan komprehensif sehingga hal tersebut dapat dijadikan solusi "final" dalam memecahkan kebuntuan persoalan kasuskasus anak yang terdapat di negara Indonesia.

\section{Pustaka Acuan}

Abdullah, M. Amin. "Bangunan Baru Epistemologi Keilmuan Studi Hukum Islam dalam Merespon Globalisasi.” Asy-Syir'ah 46, no. 2 (2012). 
Achmad, Ika Fadilah, Lutfatul Latifah, dan Dewi Natalia Husadayanti. "Hubungan Tipe Pola Asuh Orang Tua dengan Emotional Quotient (EQ) pada Anak Usia Prasekolah (3-5 Tahun) di TK Islam Al-Fattaah Sumampir Purwokerto Utara." Jurnal Keperawatan Soedirman 5, no. 1 (2010): 47-57.

Aini, Luthfiah Nur. "Hubungan Pola Asuh Orang Tua dengan Kenakalan Remaja di RW V Kelurahan Sidokare Kecamatan Sidoarjo.” Jurnal Keperawatan dan Kebidanan 6, no. 1 (2017).

Aisyah, Siti. "Pengaruh Pola Asuh Orang Tua Terhadap Tingkat Agresivitas Anak." Jurnal medtek 2, no. 1 (2010): 26-53.

Asrar, Muhamad, Hamam Hadi, dan Dradjat Boediman. "Pola Asuh, Pola Makan, Asupan Zat Gizi dan Hubungannya dengan Status Gizi Anak Balita Masyarakat Suku Nuaulu di Kecamatan Amahai Kabupaten Maluku Tengah Provinsi Maluku.” Jurnal Gizi Klinik Indonesia 6, no. 2 (2009): 84-94.

Ambary, Hasan Muarif. Menemukan Jejak Arkeologis dan Historis Islam. Jakarta: Logos, 1998.

Anderson, James Norman Dalrymple. Islamic law in the modern World. New York University Press, 1959.

Andari, Annisa Jihan. "Analisis Viktimisasi Struktural Terhadap Tiga Korban Perdagangan Perempuan dan Anak Perempuan.” Jurnal Kriminologi Indonesia 7, no. 3 (2012).

Arifin, Bustanul. Dimensi Hukum Islam dalam Hukum Nasional. Jakarta: Gema Insani Press, 1999

Ash Shiddieqy, Tengku Muhammad Hasbi. Pengantar Figh Mu'amalah. Semarang: PT. Pustaka Rizki Putra, 1997.

Assegaf, Ahmad Abdullah. Islam dan KB. Jakarta: Lentera Basritama, 1997.

Astuti, Marfu'ah Panji. "Pelanggaran Hak-Hak Anak di Sekitar Kita", Nakita, 26 Juli 2003.

Asyhari, M.A. dan Khoiroh, Ummu. Kupinang Engkau Secara Islami, Surabaya: Putra Pelajar, 2001. 
Azhim, Syakir Abdul. Membimbing Anak Trampil Berbahasa. Jakarta: Gema Insani, 2002

Baharist, Adnan Hasan Shalih. Tanggung Jawab Ayah terhadap Anak Laki-Laki. Jakarta: Gema Insani Press, 1996.

Berman, Harold J. Law and Revolution:The Formation of the Western Legal Tradition. Cambridge: Massachusetts and London, England: Harvard University Press, 1983.

Bik Nasif, Hadlarat Hifni, dkk. Qawaî̀ al-Lughah al-Arabiyyah. Surabaya: Syirkah Maktabah wa Mathba’ah, t.t.

Brilian, Armando "Perlindungan Hukum Terhadap Anak yang Menjadi Korban Tindak Pidana Perkosaan", Lex Crimen 2, No. 7, (November 2013).

Coulson, Noel. A history of Islamic Law. Routledge, 2017.

Depdikbud. Kamus Besar Bahasa Indonesia. Jakarta: Pusat Pembinaan dan Perkembangan Bahasa, dan Balai Pustaka, 1998.

Dwiatmodjo, Haryanto. "Pelaksanaan Perlindungan Hukum terhadap Anak yang Menjadi Korban Tindak Pidana di Wilayah Hukum Pengadilan Negeri Banyumas." Jurnal Dinamika Hukum 11, no. 2 (2011): 201-213.

Djaenab. "Perlindungan Anak Perspektif Fiqh dan Perundang-undangan”, Jurnal Al-Risalah 10 No. 1 (Mei 2010).

Effendy, Bahtiar. Islam dan Negara: Transformasi Pemikiran dan Praktik Politik Islam di Indonesia. Jakarta: Paramadina, 1998.

Diana, Fivi Melva. "Hubungan Pola Asuh dengan Status Gizi Anak Batita di Kecamatan Kuranji Kelurahan Pasar Ambacang Kota Padang tahun 2004." Jurnal Kesehatan Masyarakat Andalas 1, no. 1 (2006): 19-23.

Dwiati, Ira. "Perlindungan Hukum Terhadap Korban Tindak Pidana Perkosaan dalam Peradilan Pidana.” PhD diss., Program Pasca Sarjana Universitas Diponegoro, 2007.

Endrawati, Netty. "Perlindungan Hukum Terhadap Pekerja Anak Di Sektor Informal (Studi Kasus di Kota Kediri).” Jurnal Dinamika Hukum 12, no. 2 (2012): 270-283. 
Fathurrahman, Ayief. "Meninjau Ulang Landasan Normatif Perbankan Syariah di Indonesia (Telaah atas Teori Kontruksi Fiqh Klasik).” AlMawarid 11, no. 1 (2013).

Fanani, Ahwan. "Ushûl al-Fiqh Versus Hermeneutika Tentang Pengembangan Pemikiran Hukum Islam Kontemporer." Islamica: Jurnal Studi Keislaman 4, no. 2 (2010): 194-209.

Goitein, S.D. "The Birth -Hour of Muslim Law; an Essay in Exegesis" dalam Jurnal The Muslim World. Hartdford: The Hartdford Seminary Foundation, 1960.

Giovani, Prints Rayenda. "Perlindungan Hukum Terhadap Anak Korban Kejahatan Perkosaan dalam Pemberitaan Media Masa”, Jurnal Mahupiki Fakultas Hukum Universitas Sumatera Utara 1, No. 1, (2013).

Hadikusuma, Hilman. Bahasa Hukum Indonesia, Bandung: Alumni, 1992. Hadisuprapto, Paulus. "Masalah Perlindungan Hukum Bagi Anak." Dalam Seminar Nasional Peradilan Anak, Bandung, Fakultas Hukum Universitas Padjajaran. 1996.

Hadi, Abdul, dan Shofyan Hasan. "Pengaruh Hukum Islam dalam Pengembangan Hukum di Indonesia." Nurani: Jurnal Kajian Syariah dan Masyarakat 15, no. 2 (2015): 89-100.

Halil, Rasyad Hasan. Tarikh Tasyri' Sejarah Legislasi Hukum Islam. Jakarta: Amzah, 2009.

Halim, M Nipan Abdul. Membahagiakan Suami Sejak Malam Pertama. Yogyakarta: Mitra Pustaka, 2005.

Harahap, Irwan Safaruddin. "Perlindungan Hukum Terhadap Anak Korban Kejahatan Seksual dalam Perspektif Hukum Progresif." Jurnal Media Hukum 23, no. 1 (2016): 11.

Hurlock, Elizabeth B. Psikologi Perkembangan, Jakarta: Erlangga, t.t.

Husaini, Adian. "RUU Kesetaraan Gender Perspektif Islam", Islamia: Jurnal Pemikiran Islam Republika, Kamis, 22 Maret 2012.

Husein, Abdul Rozak. Hak-Hak Anak dalam Islam, Jakarta: Fikahati, Aneska, 1992. 
Hutabarat, Ramly. Kedudukan Hukum Islam dalam Konstitusi-konstitusi Indonesia dan Peranannya dalam Pembinaan Hukum Nasional. Jakarta: Pusat Studi Hukum Tata Negara UI, 2005.

Hidayati, Nur. "Perlindungan Anak terhadap Kejahatan Kekerasan Seksual (Pedofilia)." Ragam Jurnal Pengembangan Humaniora 14, no. 1 (2014): 68-73.

HZ, Evi Deliana. "Perlindungan Hukum Terhadap Anak Dari Konten Berbahaya Dalam Media Cetak Dan Elektronik." Jurnal Ilmu Hukum Riau 3, no. 2 (2012).

Ilyasin, Mukhammad. "Filsafat Hukum Islam: Implikasi Logis terhadap Konstruksi Pendidikan Islam" dalam Asy-Syir'ah:Jurnal Ilmu Syariah dan Hukum 46, No. 2 (Juli-Desember 2012).

Imaniyati, Neni Sri. "Perkembangan Regulasi Perbankan Syariah di Indonesia: Peluang dan Tantangan.” Syiar Hukum 11, no. 1 (2009): 21-38.

Imron, Ali. "Kontribusi Hukum Islam Terhadap Pembangunan Hukum Nasional (Studi Tentang Konsepsi Taklif dan Masuliyyat dalam Legislasi Hukum).” PhD diss., Program Pascasarjana Universitas Diponegoro, 2008. , "Kontribusi Hukum Islam Terhadap Pembangunan Hukum Nasional.” Jurnal MMH (2008).

Indirati, Noer. "Pengembangan Model Perlindungan Hukum terhadap Anak sebagai Korban Perdagangan di Indonesia." Jurnal Dinamika Hukum 14, no. 3 (2014): 406-418.

Jauhari, Iman. Advokasi Hak-Hak Anak Ditinjau dari Hukum Islam dan Peraturan Perundang-undangan, Medan: Pustaka Bangsa, 2008. , Perlindungan Hukum terhadap Anak dalam Keluarga Poligami. Jakarta: Pustaka Bangsa Press, 2003.

Juraidi. Jerat Perbudakan Masa Kini. Jakarta: Bina Purna Pariwara, 2003. Kartono, Katini. Psikologi Anak. Bandung: Mandar Maju, Cet.V . 1995. Khallaf, Abdul Wahab. Ilmu Ushûl al-Fiqh. Cairo: Maktabah al-Dakwah al-Islamiyah Shabab al-Azhar, 1990. 
Khaeruman, Badri. "Al-Qaradawi dan Orientasi Pemikiran Hukum Islam untuk Menjawab Tuntutan Perubahan Sosial." Wawasan: Jurnal Ilmiah Agama dan Sosial Budaya 1, no. 2 (2016): 227-238.

Konoras, Isyana K. "Perlindungan Hukum Terhadap Anak di Luar Nikah di Indonesia”, Jurnal Hukum Unsrat 1, No. 2, (April-Juni 2013).

Kusuma, Ayu Amalia. "Efektivitas Undang-Undang Perlindungan Anak dalam Hubungan dengan Perlindungan Hukum Terhadap Anak Korban Perdagangan Orang di Indonesia." Lex Et Societatis 3, no. 1 (2015).

Lopa, Baharuddin. Al-Qur'an dan Hak Asasi Manusia. Yogyakarta: Dana Bhakti Prima Yasa, 1996.

Lubis, Afisah Wardah. "Memahami Perkembangan Psikologi Anak dalam Rangka Implementasi Perlindungan Anak", Majalah Konvensi 2. No. 1 (Maret 1998), LAAI, Medan.

Mas, Marwan. Pengantar Ilmu Hukum. Bogor: Ghalia Indonesia, 2011. Mas'adi, Ghufron. Figh Muamalah Kontekstual. Jakarta: PT Raja Grafindo Persada, 2002.

Maidin, Gultom. Perlindungan Hukum Terhadap Anak dan Perempuan. Bandung: Refika Adidatama, (2012).

Monks, F.J. Psikologi Perkembangan. Yogyakarta: UGM Press, 1985.

Mufti, Muhamad Ahmad dan al-Wakil, Sami Salih. HAM Menurut Barat dan HAM menurut Islam, (terj) Yahya Abd Rahman. Bogor: Pustaka Thariqul Izzah, 2009.

Mujibatun, Siti. Pengantar Figh Muamalah. Semarang: Lembaga Studi Sosial dan Agama, 2012.

Muhammad. "Aspek Perlindungan Anak dalam Tindak Kekerasan (Bullying) terhadap Siswa Korban Kekerasan di Sekolah (Studi Kasus di Smk Kabupaten Banyumas)." Jurnal Dinamika Hukum 9, no. 3 (2009): 268-274.

Munir, Sirojul. "Pengaruh Hukum Islam Terhadap Politik Hukum Indonesia." Istinbath: Jurnal Hukum Islam IAIN Mataram 13, no. 2 (2014): 127-180. 
Musa, Kamil. Anak Perempuan dalam Konsep Islam. Jakarta: CV. Firdaus, 1994.

Muslehuddin, Muhammad. Filsafat Hukum Islam dan Pemikiran Orientalis Studi Perbandingan Sistem Hukum Islam. Yogyakarta: PT. Tiara Wacana Yogya, 1991.

Mustakim, Abdul. "Kedudukan dan Hak-hak Anak dalam Perspektif al-Qur'an”, Jurnal Musawa 4, No. 2, (Juli 2006): 149-50.

Muzakki, Ahmad. Gus Dur: Pembaharu Pendidikan Humanis Islam Indonesia Abad 21. Yogyakarta: Idea Press, 2013.

Munawwar, Said Agil Husain al-. Islam dan Pluralitas Masyarakat Indonesia. Jakarta: Kaifa, 2004

Nadia, A., September. Penganiayaan Terhadap Anak dalam keluarga. Dalam Makalah Seminar Kekerasan Anak: Efek Psikis, Fisik, dan Tinjauan Agama (2004): 13-19.

Nasution, Mustafa Edwin, and Uswatun Hasanah. Wakaf Tunai Inovasi Finansial Islam: Peluang dan Tantangan dalam Mewujudkan Kesejahteraan Umat. Pusat Kajian Timur Tengah dan Islam Universitas Indonesia bekerja sama dengan Bank Indonesia, didukung oleh Departemen Agama RI, 2006.

Nainggolan, Marsaulina, Elvi Zahara, dan Saparuddin Saparuddin. "Peranan Hakim dalam Memberikan Perlindungan Hukum terhadap Anak Korban Penyalahgunaan Narkotika (Studi Pengadilan Negeri Lubuk Pakam).” Jurnal Mercatoria 3, no. 2 (2010): 116-132.

Nawawi, al-Imam al-. Al-Majmû' Syarah Al-Muhazdzdzab. Ttp.: Tnp., t.t. Nurwijayanti, Andriyani Mustika. "Eksploitasi Anak: Perlindungan Hukum Anak Jalanan Dalam Perspektif Hukum Pidana Di Daerah Yogyakarta.” PhD diss., Universitas Muhammadiyah Surakarta, 2012.

Noviana, I., Kekerasan Seksual Terhadap Anak: Dampak dan Penanganannya. Sosio Informa (2015).

Passalbessy, John D. "Dampak Tindak Kekerasan Terhadap Perempuan dan Anak serta Solusinya." Jurnal Sasi 16, no. 3 (2010).

Pramawaty, Nisha, dan Elis Hartati. "Hubungan Pola Asuh Orang Tua dengan Konsep Diri Anak Usia Sekolah (10-12 Tahun).” Jurnal Keperawatan Diponegoro 1, no. 1 (2012): 87-92. 
Pratiwi, A. Wira. "Tinjauan Yuridis Tindak Pidana Persetubuhan Terhadap Anak Secara Berlanjut.” Jurnal Fakultas Hukum (2012).

Prinst, Darwin. Hukum Anak Indonesia. Bandung: PT. Citra Aditya Bakti, 1997.

Probosiwi, Ratih, dan Daud Bahransyaf. "Pedofilia dan Kekerasan Seksual: Masalah dan Perlindungan Terhadap Anak." Sosio Informa (2015).

Razi, Muhammad al-. Tafsir al-Fakhr al-Razi. Bayrut, Libanon: Dar al-Fikr, 1994.

Rozak, Purnama. "Kekerasan Terhadap Anak dalam Rumah Tangga Perspektif Hukum Islam”, Jurnal Sawwa 9, No. 1, (Oktober 2013).

Pusat Bahasa Departemen Pendidikan Nasional. Kamus Besar Bahasa Indonesia. Jakarta: Balai Pustaka, 2002.

Rahmad, Jalaluddin. Islam Aktual: Refleksi Sosial Seorang Cendekiawan Muslim. Bandung: Mizan, 2001.

Ramayulis, dkk. Pendidikan Islam dalam Rumah Tangga. Jakarta: Kalam Mulia, 2001.

Rasdiyanah, Andi. "Kontribusi Hukum Islam dalam Mewujudkan Hukum Pidana Nasional." Dalam Makalah Disampaikan pada upacara Pembukaan Seminar Nasional tentang Kontribusi Hukum Islam Terhadap Terwujudnya Hukum Pidana Nasional yang Berjiwa Kebangsaan, UII-Yogyakarta, vol. 2. 1995.

Rusni. "Fenomena Kekerasan Seksual Terhadap Anak." Shautut Tarbiyah 35, no. 2 (2017): 51-68.

Sanjiwani, N. L. P. Y., dan I. GAPW Budisetyani. "Pola Asuh Permisif Ibu dan Perilaku Merokok pada Remaja Laki-Laki di SMA Negeri 1 Semarapura." Jurnal Psikologi Udayana 1, no. 2 (2014): 344-352. Safitri, Yuhanda, dan Eny Hidayati. "Hubungan Antara Pola Asuh Orang Tua dengan Tingkat Depresi Remaja di SMK 10 November Semarang." Jurnal Keperawatan Jiwa 1, no. 1 (2013).

Saleh, Fauzi. "Problematika Talfiq Mazhab dalam Penemuan Hukum Islam.” Islamica: Jurnal Studi Keislaman 6, no. 1 (2011): 66-73.

Schacht, Joseph. An Introduction to Islamic Law. Oxford: Oxford University Press, 1964. 
Shafiyarrahman, Abu Hadiyan. Hak-Hak Anak dalam Syariat Islam. Yogyakarta: Al-Manar, 2003.

Siswandi, Imran. "Perlindungan Anak dalam Perspektif Hukum Islam dan HAM", dalam Jurnal Al-Mawarid 11, No. 2, (Sept - Jan 2011).

Sinaga, Sontan Merauke, and Elvi Zahara Lubis. "Perlindungan Hukum terhadap Anak Yang Melakukan Kejahatan dalam Persidangan Anak." Jurnal Mercatoria 3, no. 1 (2010): 52-57.

Sudarti, Elly. "Perlindungan Hukum Terhadap Anak dalam Proses Ajudikasi." Jurnal Ilmu Hukum Jambi 2, no. 2 (2014).

Sugianto. "Menghindari Kekerasan Terhadap Anak Menurut Perspektif Undang-Undang Perlindungan Anak", dalam Jurnal de Jure, Jurnal Syariah dan Hukum 4, No. 1, (Juli 2012).

Suja', Abu. Fathul Qorib Mujib (Taqrib). Bandung: Ma’arif, tt.

Suharsono, Joko Tri, Aris Fitriyani, and Arif Setyo Upoyo. "Hubungan Pola Asuh Orang Tua Terhadap Kemampuan Sosialisasi pada Anak Prasekolah di TK Pertiwi Purwokerto Utara." Jurnal Keperawatan Soedirman 4, no. 3 (2009): 112-118.

Sulaiman, Abu Dawud. Sunan Abi Dawud. Bayrut, Libanon: al-Kutub al-Islamiyah, 1996.

Sularno, M. "Syari'at Islam dan Upaya Pembentukan Hukum Positif di Indonesia." Al-Mawarid 16 (2006).

Suhirman, Gatot. "Fiqh Mazhab Indonesia (Konsep dan Aplikasi Pemikiran Hasbi as-Siddiqi untuk Konteks Islam Rahmat li-Indonesia).” AlMawarid 11, no. 1 (2013).

Sumiarni, MG Endang. Perlindungan Hukum Terhadap Anak dalam Hukum Pidana. Yogyakarta: Universitas Atma Jaya, 2003. , dan Chandera Halim. Perlindungan Hukum Terhadap Anak dalam Hukum Keluarga. Yogyakarta: Universitas Atmajaya, 2000. , Perlindungan Hukum terhadap Anak Dibidang Kesejahteraan. Yogyakarta: Universitas Atma Jaya, 2000.

Sunarty, Kustiah. "Implementasi Model Pola Asuh Orang Tua untuk Meningkatkan Kemandirian Anak.” Journal Of Educational Science and Technology 1, no. 1 (2015): 1-93. 
Suryanegara, Ahmad Mansur. Menemukan Sejarah. Bandung: Mizan, 1995. Solihin, Lianny. "Tindakan Kekerasan pada Anak dalam Keluarga.” Jurnal Pendidikan Penabur 3, no. 3 (2004): 133.

Tim Redaksi, Undang-Undang Perlindungan Anak: Undang-uUndang RI Nomor 23 Tahun 2002, Bandung: Fokusmedia, 2007.

Ubaidillah, M. Hasan. "Kontribusi Hukum Islam dalam Mewujudkan Good Governance di Indonesia." Al-Qanun: Jurnal Pemikiran dan Pembaharuan Hukum Islam 11, no. 1 Juni (2008): 112-141.

Unicef, "Domestic Violence Againts Women and Girl', 2000 dikutip dari Lufita Tria "Psychological Violence", 2012, dalam http://psychologicalspot. wordpress.com/2012/02/22/teoriHarisa, "Teori Tipologi Bentuk Kekerasan Psikologis Terhadap Anak (Child) tipologi-bentuk-kekerasanpsikologis-terhadap-anak-child-psychological-violence, [22-02- 2012]. Universal Declaration of Human Right dalam http://www.ohchr.org/EN/ UDHR/ Pages/Language. aspx?LangID=inz

Wahjoetomo. Perguruan Tinggi Pesantren: Pendidikan Alternatif Masa Depan. Jakarta: Gema Insani Press, 1997.

Wahyudi, Dheny. "Perlindungan Terhadap Anak yang Berhadapan dengan Hukum Melalui Pendekatan Restorative Justice.” Jurnal Ilmu Hukum Jambi 6, no. 1 (2015).

Wahyuni, Fitri. "Sanksi Pidana Pemerkosaan Terhadap Anak Menurut Hukum Pidana Positif dan Hukum Pidana Islam.” Jurnal Media Hukum 23, no. 1 (2016): 15.

Wadong, Maulana Hasan. Advokasi dan Hukum Perlindungan Anak. Jakarta: Grasindo, 2000.

Yatim, Badri. Sejarah Peradaban Islam. Jakarta: PT. Raja Grafindo Persada, 2000.

Yanto, Oksidelfa. "Prostitusi Online Sebagai Kejahatan Kemanusiaan Terhadap Anak: Telaah Hukum Islam dan Hukum Positif." Ahkam: Jurnal Ilmu Syariah 16, no. 2 (2016): 187-196.

Zai, Ariyunus, and Taufik Siregar. "Perlindungan Hukum terhadap Anak yang Berhadapan dengan Hukum dalam Sistem Peradilan Anak (Studi pada Wilayah Hukum Polres Nias).” Jurnal Mercatoria 4, no. 2 (2011): 99-116. 
Zaki, Muhammad. "Perlindungan Anak dalam Perspektif Islam” Jurnal ASAS 6, No.2, (Juli 2014).

Zuhaily, Wahbah al-. Al-Fiqhul Islâmî Wa Adillathî, Ttp.: Dar al-Fikr, t.t. 